Portland State University

PDXScholar

1-20-1994

\title{
An Assessment of the Riparian-influenced Salmonid Habitat Features of Johnson Creek, Portland, Oregon
}

Andrew Greiff Gude

Portland State University

Follow this and additional works at: https://pdxscholar.library.pdx.edu/open_access_etds

Part of the Geography Commons

Let us know how access to this document benefits you.

Recommended Citation

Gude, Andrew Greiff, "An Assessment of the Riparian-influenced Salmonid Habitat Features of Johnson Creek, Portland, Oregon" (1994). Dissertations and Theses. Paper 5232.

https://doi.org/10.15760/etd.7104

This Thesis is brought to you for free and open access. It has been accepted for inclusion in Dissertations and Theses by an authorized administrator of PDXScholar. Please contact us if we can make this document more accessible: pdxscholar@pdx.edu. 


\section{THESIS APPROVAL}

The abstract and thesis of Andrew Greiff Gude for the Master of Science in Geography were presented 20 January 1994, and accepted by the thesis committee and the department.

COMMITTEE APPROVALS:

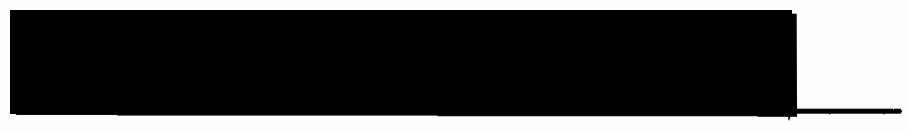

Teresa L. Bulman, Chair

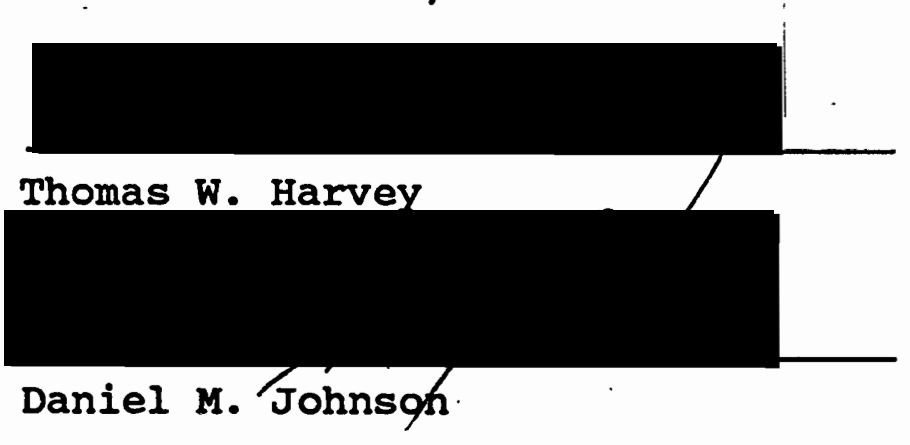

DEPARTMENTAL APPROVAL:

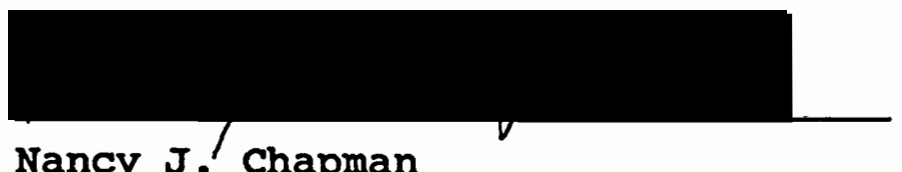

Nancy J. Chapman

Representative of the office of Graduate Studies

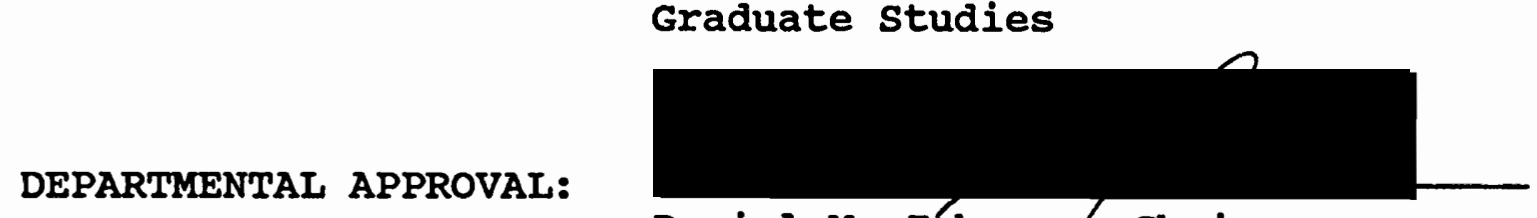

Daniel M. Jóhnson, Chair Department of Geography

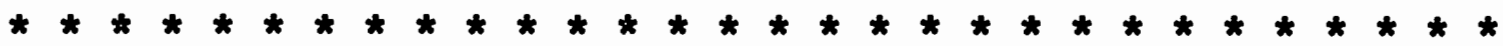

ACCEPTED FOR PORTLAND STATE UNIVERSITY BY THE LIBRARY by

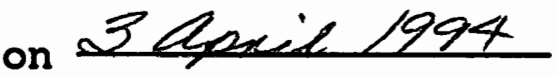




\section{ABSTRACT}

An abstract of the thesis of Andrew Greiff Gude for the Master of Science in Geography presented 20 January 1994.

Title: An Assessment of the Riparian-Influenced salmonid Habitat Features of Johnson Creek, Portland, oregon.

Pacific salmon populations in Johnson Creek, Portland, Oregon have been adversely impacted by urbanization, and by residential and agricultural land development. | Ecological impacts include loss or depletion of riparian vegetation features which directly influence stream and associated salmonid ecology. This research examines the nearstream riparian zone's contribution to instream habitat complexity for anadromous salmonids in Johnson Creek. Visual surveys were conducted on over half the stream length. Five features were assessed to determine the extent of riparianinfluenced stream habitat including, overhead enclosure, overhanging vegetation, undercut banks, and large and small woody debris and root wads. The stream survey showed that areas of riparian-influenced habitat are spatially intermittent and present in areas of the least stream disturbance. Suitable riparian habitat is limited to 
locations where there is minimal riparian disturbance, property management, and channelization. Although salmonid populations have been reduced, insufficient riparianinfluenced salmonid habitat features are not the primary limiting factor on salmon populations. Other factors such as pollution, sedimentation, hatchery fish introduction, low flows, inadequate food supplies, high stream temperatures, repress wild salmon populations 
AN ASSESSMENT OF THE RIPARIAN-INFLUENCED SAIMONID HABITAT FEATURES OF JOHNSON CREEK, PORTLAND, OREGON

by

ANDREW GREIFF GUDE

A thesis submitted in partial fulfillment of the requirements for the degree of

MASTER OF SCIENCE
in
GEOGRAPHY

Portland state University

1994 


\section{ACKNOWLEDGEMENTS}

The completion of my graduate studies and this thesis would not have been possible without the patience and support of my wife Evelyn Monroe Gude. My advisor, Dr. Teresa Bulman, devoted considerable time and effort in helping me with my studies and the thesis manuscript. Committee members Dr. Tom Harvey, Dr. Dan Johnson, and Dr. Nancy Chapman provided additional guidance to my endeavors. Ms. Carolyn Perry deserves significant recognition for the care, effort, technical expertise, and advice she has given me since my first day in the department. To all these people specifically, and to the entire department of Geography, its faculty and students, I am most grateful. 
TABLE OF CONTENTS

PAGE

ACKNOWLEDGEMENTS

LIST OF TABLES

vi

LIST OF FIGURES

vii

IIST OF PLATES

CHAPTER

I INTRODUCTION . . . . . . . . . . 1

II LITERATURE REVIEW . . . . . . . . . 10

Urban Streams ......... . . 10

Habitat Surveys . . . . . . . 11

Previous Studies on Johnson Creek • 12

Salmonids . . . . . . . . . 14

Johnson Creek Fisheries . . . . 15

Riparian Vegetation's Influence on Salmonid Ecology .......

Stream Cover

Temperature

Woody Debris

Food Supply

Vegetation Rooting

III PHYSICAL GEOGRAPHY AND SALMONIDS OF JOHNSON CREEK WATERSHED . . . . . 24

Salmonids in Johnson Creek . . . 24

Location . . . . . . . . . 27

Climate . . . . . . . . . . 29

Geology, Geomorphology, and 
Soils • • • • • • • • • • • •

Groundwater . . . . . . - .

Surface Waters . . . . . . . .

Historical Land Use . . . . . . 34

Effects of Urbanization . . . . 38

Water Quality . . . . . . . 41

IV METHODOLOGY • . . . . . . . . . . . . 44

V RESULTS •. . . . . . . . . . . . • 54

Reach 1 . . . . . . . . . . 54

Section 1A

section 1B

Section 1C

Reach 2 . . . . . . . . . 60

Section 2A

Section 2B

section 2C

$\operatorname{Reach} 3$...$\cdot$. . . . . .

Section 3A

Section 3B

section $3 \mathrm{C}$

Summary of Results . . . . . . .

VI DISCUSSION • . • . • • . • • • • •

VI CONCLUSIONS • • • • • • • • • • • 


\section{LIST OF TABLES}

TABLE

PAGE

I Effects of Riparian Zone Disturbance . .

II Riparian Vegetation Functions in Relation to a Stream Ecosystem . . . . . . 18

III Salmonids in Johnson Creek . . . . . . . 25

IV General Land Use in the Nine Sections

Sampled Along Johnson Creek . . . $\quad 47$

V Results of Survey on Reach 1 . . . . . . 55

VI Results of Survey on Reach 2 . . . . . . 61

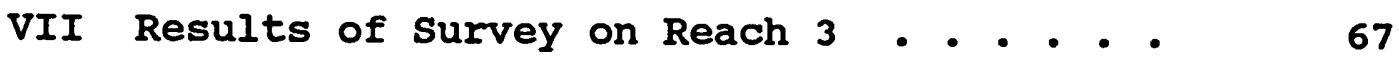

VIII Summary of Results by Sample section . . 73

IX Extrapolated Values for Quantities of

Riparian-Influenced Salmonid

Habitat Features Along Johnson Creek 


\section{LIST OF FIGURES}

FIGURE

PAGE

1. Johnson Creek Watershed in Portland,

Oregon . . . . . . . . . . . 2

2. Riparian Zone Cross Section . . . . . 5

3. Stream Profile of Johnson Creek . . . . 28

4. The Three Physiographic Regions in the Johnson Creek Basin . . . . . . 30

5. Underlying Geology of the Johnson Creek Basin . . . . . . . . . . 31

6. Hydrograph of Johnson Creek Depicting Average Monthly Flow . . . . . 35

7. Stream Overhead Enclosure . . . . . . 48

8. Overhanging Vegetation and an Undercut Bank . . . . . . . . . . . 50

9. Root Wad . . . . . . . . . . . 51

10. A Stream Channel with Large and Small Woody Debris . . . . . . . •

11. Average Percent Overhead Enclosure per

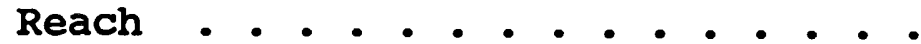

12. Average Percent Overhanging Vegetation per Reach • . . - . . - . - • 
13. Average Feet per Mile of Undercut Banks per Reach • . . • . . • . . •

14. Average Number of Small Root Wads per

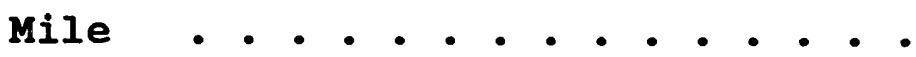

15. Average Number of Large Root Wads per Mile • • • • • • • • • • •

16. Average Number of Small Woody Debris per Mile . . . . . . . . . .

17. Average Number of Large Woody Debris per Mile • • • • • • • • • • •

18. Comparison of Habitat Features Between Reaches - . . . . . . . .

19. Relative Overall Habitat Feature

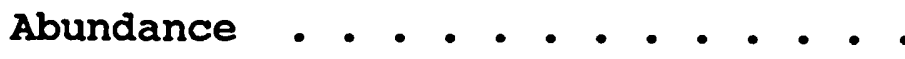




\section{LIST OF PLATES}

\section{PIATE}

1. Land Use in the Johnson Creek Basin

2. Water Quality Problems

3. The Three Reaches and Nine Surveyed Sections

4. Location of Significant Habitat Areas Along Johnson Creek 


\section{CHAPTER I}

\section{INTRODUCTION}

Johnson Creek, a tributary of the lower willamette River in Southeast Portland, Oregon (Figure 1), is ecologically significant because it supports limited runs of wild, anadromous salmon, despite extensive urbanization in the watershed. Salmon populations in Johnson Creek are low, due to seven decades of detrimental effects of urbanization, and residential and agricultural land development, including increased impervious areas, soil compaction, and channel alterations. Land use change is the leading factor in the decline of fisheries resources in stream ecosystems in the United states (Karr et al. 1985; Salo and Cundy 1987). Urban development in the Johnson Creek basin has been the principal cause of salmonid population and stream health declines (Oregon Department of Environmental Quality 1975). (Salmonids have three important life events - spawning, incubation, and rearing. The different lifestages and species require various kinds of physical habitat and spatial heterogeneity, and the maintenance of connectivity between habitat areas, all of which are critical for fish survival. Generally, good salmonid stream habitat has a high diversity of habitat types. 
2
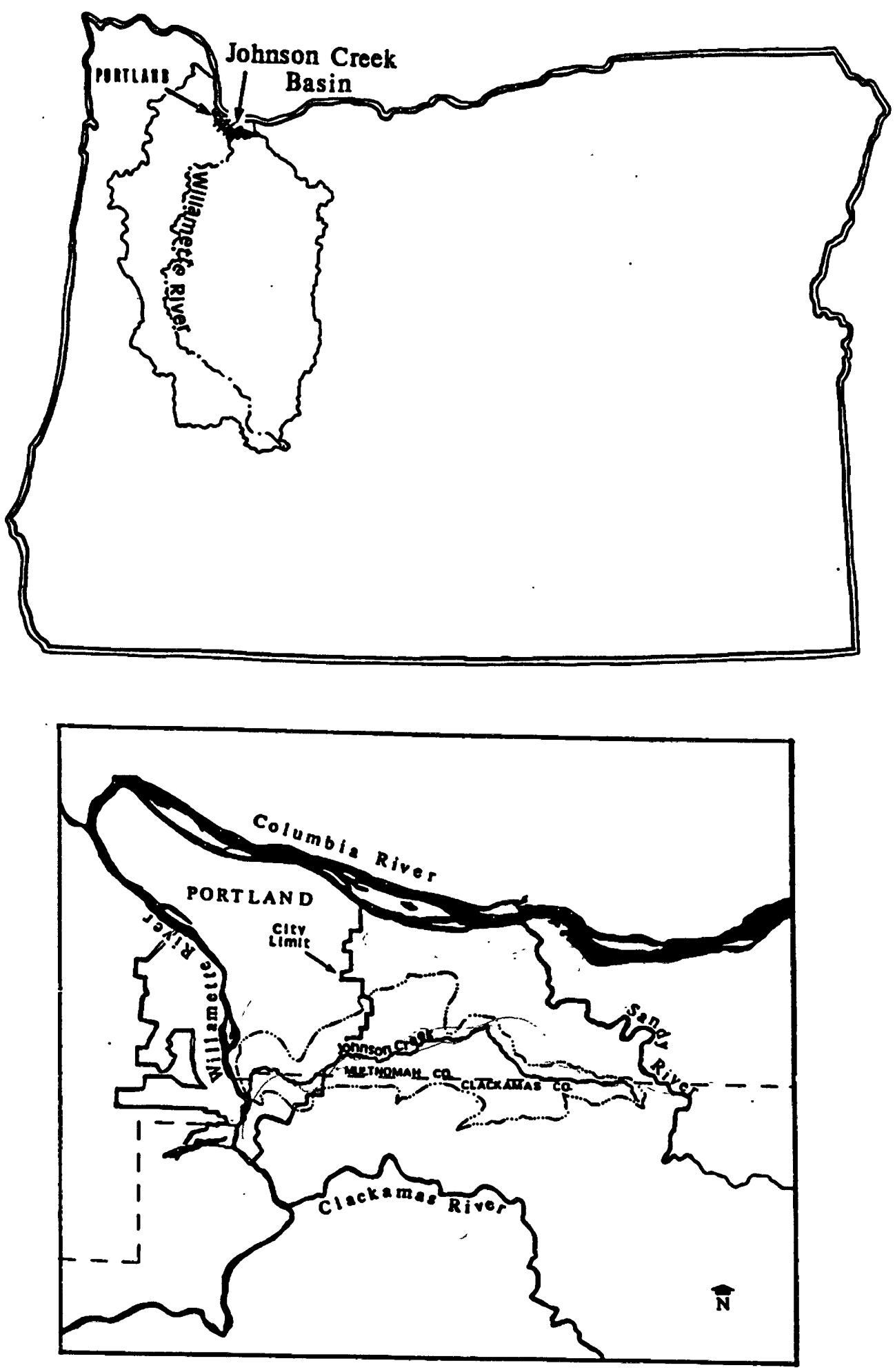

Figure 1. Johnson Creek watershed in Portland, Oregon. 
Loss or depletion of riparian vegetation due to urban development directly influences stream and salmonid ecology. This research examines the riparian zone's contribution to stream habitat for anadromous salmon in Johnson Creek. The hypothesis of this thesis is that the physical features which make up riparian-influenced salmonid habitat are not abundant in Johnson Creek due to the effects of urbanization. Though salmonid populations have been reduced, insufficient riparian-influenced salmonid habitat features are not the primary limiting factor on their populations. Other factors such as pollution, sedimentation, hatchery fish introduction, low flows, and high stream temperatures, contribute to or repress wild salmon populations.

The research objectives of this thesis are to:

1. Describe geographical differences in stream reaches of the Johnson Creek corridor (the riparian zone), the creek, and watershed.

2. Analyze the abundance of riparian vegetation's contribution to instream habitat through a qualitative survey of riparian habitat features along Johnson Creek.

3. Suggest resource management recommendations related to riparian-influenced salmonid habitat features for improving salmon populations. 
Streamside forests and associated riparian vegetation are important to fisheries habitat, determining habitat complexity and diversity in a stream ecosystem (Bisson et al. 1987; Sullivan et al. 1987). Adverse impacts in the riparian zone exert the greatest influence on stream habitat quality for salmon. The riparian zone is a three dimensional zone interacting directly with the fluvial and terrestrial ecosystems, stretching out horizontally from the stream channel to the flood limit, and vertically into the canopy of streamside vegetation (Figure 2) (Meehan et al. 1977). Riparian vegetation, such as herbaceous ground cover, understory shrubs, and overstory trees, stabilizes stream banks and adjacent slopes, promotes water quality, balances thermal regimes, influences instream habitat, and provides food sources (Reiser and Bjornn 1979).

Riparian vegetation is nonaquatic but directly affects stream morphology, habitat, and food supply (Meehan et al. 1977). The riparian zone is ecotonal, a place of transition occurring at the interface of aquatic and terrestrial ecosystems. The ecological importance of riparian zones in aquatic ecosystems is well recognized (Gregory et al. 1989; Knight and Bottorff 1984; Meehan et al. 1977; Swanson et al. 1982). However, in urban streams such as Johnson Creek, the zone's importance is greater due to the higher degree of disturbance throughout the basin. 


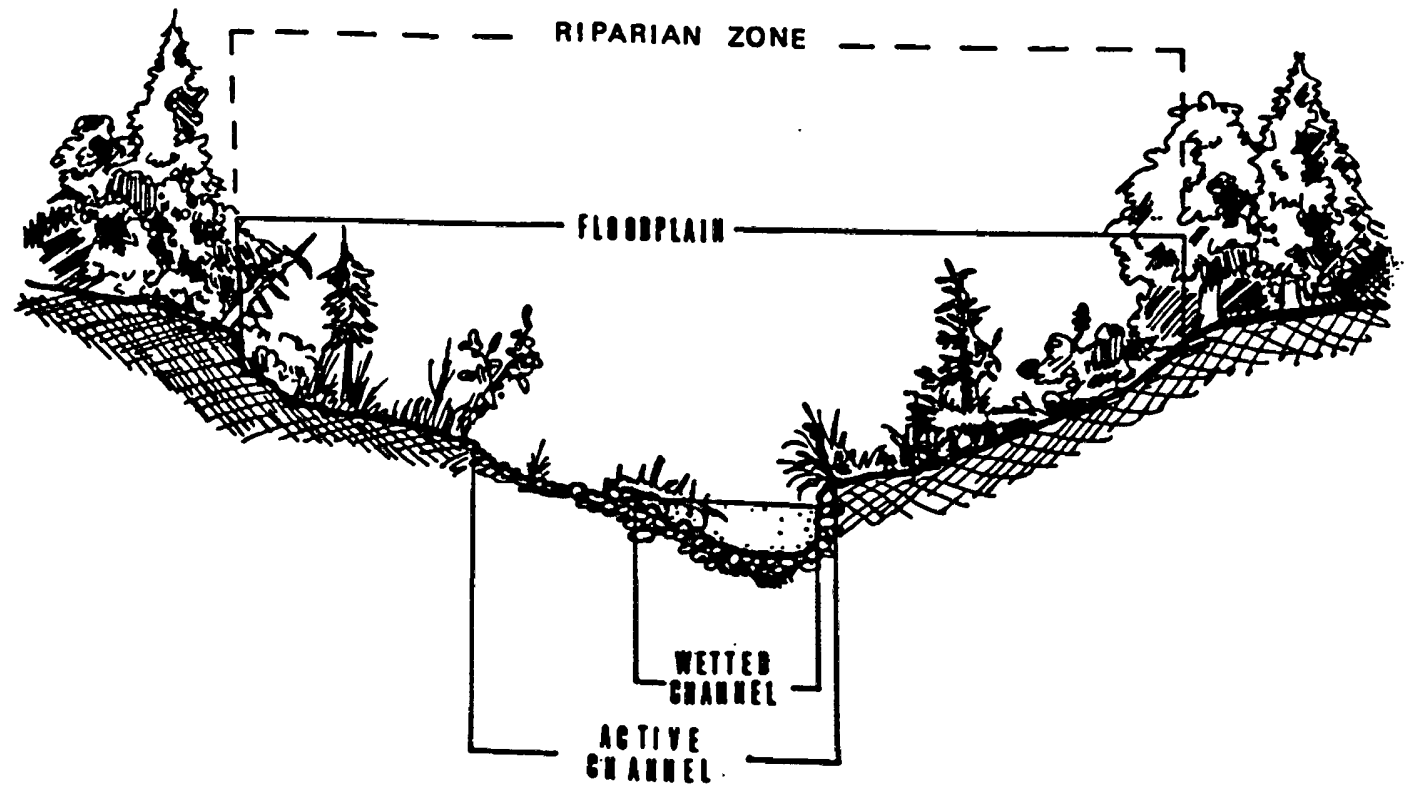

Eigure 2. Riparian zone cross section. 
The Johnson Creek basin and corridor are in physically and demographically diverse rural and urbanized areas. The basin is geographically diverse in land use (Plate 1), encompassing agriculture, rural residential areas, and urbanization. Johnson Creek is significant in the Portland Metropolitan Area as one of the few undammed streams that. supports wild salmon. Without an adequate stream protection program, Johnson Creek and its salmon population will face degradation as basin population increases in the next 20 years (Metropolitan Service District 1991). These anadromous fish serve as biological indicators for Johnson creek, with their presence representing a standard of environmental quality sufficient for a range of aquatic species. Salmonids require a cold water environment, minimal pollutants, and reasonable amounts of habitat diversity and food supply.

Historical and continued effects of urbanization and other land uses in the Johnson Creek basin and along the stream corridor have caused anadromous salmon to suffer numerous deleterious ecological consequences. Disturbance in the riparian zone can enhance other processes that act in a cumulative and harmful manner on stream dwelling organisms (Salo and Cederholm 1980; Table 1). 
TABLE I

EFFECTS OF RIPARIAN ZONE DISTURBANCE

\begin{tabular}{|ll||}
\hline \hline 1. & $\begin{array}{l}\text { Loss of riparian vegetation, decreasing physical } \\
\text { habitat. }\end{array}$ \\
\hline 2. & Changes in diurnal or seasonal temperature patterns. \\
\hline 3. & Escalation of suspended or deposited sediment. \\
\hline 4. & $\begin{array}{l}\text { Harmful alterations in water quantity and flow } \\
\text { regime. }\end{array}$ \\
\hline 5. & Detrimental changes in water quality parameters. \\
\hline 6.) & $\begin{array}{l}\text { Physical habitat alterations caused by excessive } \\
\text { increases or decreases in loads of organic material. }\end{array}$ \\
\hline
\end{tabular}

wild salmon are an icon of the Pacific Northwest region. Since the great ice masses retreated north from the continent, Pacific salmon have spawned year-round in the region's cold-water streams. In the aboriginal culture of the Pacific Northwest salmon were spiritually and physically important (Beckham et al. 1988). Early accounts of the first explorers to the oregon Territory indicated that salmon runs were present during all four seasons in most streams. Salmon have also been an integral part of nonnative culture since white settlers first arrived some 150 years ago. However, at present, wild salmon stocks are faced with unprecedented population declines in the columbia basin (Nehlsen et al. 1991, 1992; Williams et al. 1989). 
As an ecologically significant resource, the survival of wild salmon must be addressed in the management of Portland's streams. A resource management opportunity in environmental planning is presented in the case of Johnson Creek, which has limited runs of salmon, despite hundreds of riparian corridor property owners, historical impacts of stream bed and bank alteration, and pollution.

Problems with management of the creek's watershed are being addressed by government and private groups. The U.S. Environmental Protection Agency had required a water quality management plan for Johnson Creek by late 1992 to comply with the stormwater regulations of the clean water Act (City of Portland 1992C). This has now been combined with an expected city wide water management plan due in mid-1994 (Machorro 1993). Oregon's Department of Environmental Quality has determined that Johnson Creek is water quality limited and has applied management directives to protect the water (Oregon Department of Environmental Quality 1975). The Johnson Creek Watershed Management Plan is being developed to address water quality. One aspect of this plan is enhancement of the cold water fishery for salmonid populations.

Human influences throughout the catchment disrupt the natural ecological balance of the stream and near-stream environment. Effects are heightened by urbanization especially from corridor activities and land use in the 
floodplain or riparian zone. These affect salmon's physical, chemical, and biological habitat parameters. Due to their spatial proximity to the stream ecosystem, property owners along the creek have a special role in managing the riparian vegetation along the creek and influencing stream habitat features.

Even with the considerable impact of urbanization on wild salmon populations throughout the Johnson Creek basin, there may still be suitable riparian-influenced habitat available for salmon. Proper management can result in an increase in riparian vegetation influencing salmonid ecology. 
CHAPTER II

\section{LITERATURE REVIEW}

Evaluating a resource management issue, such as riparian vegetation's influence on wild salmon in Johnson Creek, from a geographic perspective permits analysis of the complex association of natural and human systems existing in the basin. Riparian areas are physically dynamic components of the landscape, playing important roles in landscape ecology and resource management (Foreman 1994, Gregory et al. 1989). In addition, the concept of the drainage basin as a spatial structure for organization and study is supported historically in human and physical geography (Dunne and Leopold 1978; Smith 1969; Teclaff 1967). A stream and its drainage provide a natural geographical unit or management framework, used increasingly in natural resource management (Lotspeich 1980).

\section{URBAN STREAMS}

Urban streams and related resources have received increased attention in recent years through workshops, symposia (Johnson and Jones 1977) and conferences (Johnson et al. 1985; Abel 1989), watershed management projects (DeBano and Schmidt 1989) and fisheries and wildlife 
restorations (Payne and Copes 1986). Public interest and education has been reflected in proactive restoration efforts (Commonwealth of Pennsylvania 1986), state riparian councils, (Patten and Hunter 1989), and landscape planning and design for stream preservation (Ferguson 1991).

Multi-objective approaches in environmental planning with community involvement have addressed hydrologic, biologic, and geomorphic factors of urban streams (Korostoff 1990; Meyer 1989; Ortiz 1989; Riley 1988, 1989; Vendlinski and Talley 1989; Williams and Swanson 1989; Williams 1993). In the Pacific Northwest, the Adopt-A-Stream Foundation restores and reclaims streams through community and school involvement in projects, workshops, and symposia; similar projects have been established elsewhere (Adopt-A-Stream Foundation 1992; Hunter 1991; Keller and Hoffman 1977; Windell et al. 1988). In Portland, the issue of citizen involvement in urban environmental planning focusing on Johnson Creek's natural areas, fisheries and wildlife, and water quality has been examined frequently (Emery 1977; Metropolitan Service District 1981, 1982; Oregon Department of Fish and Wildlife (Undated); Seltzer 1983; Westfall 1983) •

HABITAT SURVEYS

Habitat surveys serve as a basis for monitoring and evaluating stream and fisheries habitat. Partial physical 
habitat surveys were conducted on Johnson Creek in 1935 and 1991 (City of Portland 1991b). However, no complete or detailed habitat survey has ever been conducted on Johnson Creek (City of Portland 1992c). Riparian attributes (or features) serving as variables that constitute salmonid habitat have been defined, measured, and evaluated for quality and quantity in surveys on streams, and that methodology has been employed in this thesis (Bowlby and Roff 1986, Marcus et al. 1990, Platts et al. 1983, U.S. Forest service 1988, 1990). This thesis contributes data, previously lacking, on riparian-influenced salmonid habitat of Johnson Creek.

PREVIOUS STUDIES ON JOHNSON CREEK

Investigations in the Johnson Creek basin date back to the 1930s. Flooding and storm drainage management have been studied extensively (City of Portland 1987b; Clackamas County 1988, 1992b; Columbia Regional Association of Governments 1974, 1975; Gresham 1982; Metropolitan Service District 1974, 1975, 1976, 1980a, b, c, and d, 1982; U.S. Army Corps of Engineers 1958, 1973, 1975a and b, 1982, 1986, 1990, 1992), as have the fluvial hydrology, channel design, and the physical nature of the stream channel (City of Portland 1991b; U.S. Geological Survey 1990a and b; U.S. Army Corps of Engineers Undated, 1958, 1975a and b, 1982, 1992). 
Water quality, pollution, urban stormwater runoff, and related studies have been undertaken by Metropolitan service District (1980b and c), Oregon Department of Environmental Quality (1975), Portland State University (1981) and U.S. Geologic Survey $(1989,1991)$. Watershed management has been researched by oregon Department of Environmental Quality (Undated), City of Portland (1990a, 1992C), and Metropolitan Service District (1991). The U.S. Soil Conservation Service has carried out comprehensive studies detailing management practices to control erosion in the upper basin (1969, 1985). Clement (1984) found effects of urbanization in the upper Johnson Creek basin had a significant impact on the hydrologic regime.

Natural resources including fish, wildlife, vegetation, open spaces, and urban natural areas have been given considerable attention in the past few years. In the Portland area, the Metropolitan Green Spaces Program and other municipalities have included Johnson Creek as a significant natural resource (Audubon Society 1990, Undated; City of Portland 1990b; Clackamas County 1992a; Gresham 1985, 1988, 1991a, 1991b; Metropolitan Service District Undated; Seltzer 1983). Oregon Department of Fish and Wildlife $(1989,1990)$ has recent and historical natural resource data on file; water rights information on Johnson Creek has been compiled by the state (Oregon Department of Water Resources 1990). A guide to best management practices 
for the basin (City of Portland 1991a) has also been compiled.

\section{SALMONIDS}

Literature on urbanization and salmonid fisheries has dealt with toxicology of urban runoff (Davies 1986), use of benthic invertebrates for evaluating urban runoff impacts (Pedersen and Perkins 1986), and influence of urban runoff on food quality in streams (Sloane-Richey et al. 1981). studies of the influence of home development on water quality have shown varying impacts on fisheries (Gary et al. 1981; Schillinger and stuart 1978; Segall 1976). The most comprehensive study on impacts of urban development on fish populations involved a creek in Bellevue, Washington, which was compared to a pristine control stream nearby (Pedersen and Perkins 1986; Scott et al. 1986; Sloane-Richey et al. 1981). Results showed that riparian vegetation removal decreased allochthanous (introduced) debris inputs and the hydrologic regime and channel morphology changed (SloaneRichey et al. 1981). Effects of urbanization had a greater impact on salmonids in comparison to other fish, but salmonids were not displaced from the creek (Scott et al. 1986).

Hunter (1991) compiles considerable information involving salmonid fish, stream restoration and management for the lay person. Reiser and Bjornn (1979) provide the 
most comprehensive work on habitat requirements of salmon. Hunt (1976) describes trout habitat development with resource management improvement options.

\section{JOHNSON CREEK FISHERIES}

Urbanization in watersheds and stream corridors damages fisheries (Arthington et al. 1983; Katz and Gaufin 1952; Tramer and Rogers 1973; Trautman 1933). The extent of urban development within a given watershed is a function of watershed size and geographic location in relation to the population center, suggesting smaller watersheds are more influenced by spread of urbanization (Limburg and schmidt 1990)

Not all fish are as susceptible to effects of urbanization in watersheds as Pacific salmon. One of the few published studies on urban streams and fish found that despite urbanization, species richness and composition in mid-western prairie streams was similar to rural streams (Matthews and Gelwick 1990); native fish of midwestern prairie streams are, however, more tolerant of physiochemical stress (Matthews and Maness 1979; Matthews 1987) than cold water salmonids of the Pacific Northwest. Historically, fishery resources of Johnson Creek have been so damaged by pollution, obstructions and flood control work, lack of spawning gravel, and effects of the high degree of population in the region, that the creek was 
"practically useless as a salmon producer" (City of Portland 1935, 14-A). A 1935 physical habitat survey of Johnson creek, from the mouth to southeast 262 nd Avenue noted that the creek had numerous $\log$ and brush jams, including various dams, some impassable even in high water (City of Portland 1935). In combination with heavy pollution, "sawmill, domestic sewage, garbage, and doubtless (sic) barnyard debris...", the situation was serious (city of Portland 1935, 14-A). The Environmental Protection Agency (1982) and City of Portland (1992a) have conducted population and spawning surveys on the creek finding evidence of rearing and spawning salmonids. Additional information has been compiled. concerning fish species, flows, water quality, pollution, and fish kill problems in Johnson Creek (City of Portland 1990C; Massey 1990; Oregon Department of Fish and Wildlife 1989, 1990; Smythe 1990; U.S. Fish and Wildlife Service 1992).

Historical data on fisheries and habitat exist from surveys conducted by various agencies and by incidental observations. A February 1935 survey sampled four locations and showed that conditions were very unfavorable for salmon (City of Portland 1935). The Oregon Fish Commission sampled at one site in 1973, while the Environmental Protection Agency sampled fish populations in 1982 at two sites (City of Portland 1992c). The city of Portland commissioned a spawning survey in 1992, to determine the distribution and 
abundance of spawning or migrating anadromous salmon and the location of their redds (salmon nests). Observations by residents along the creek and by agency personnel during fish kill investigations account for other fisheries data (City of Portland 1992C).

\section{RIPARIAN VEGETATION'S INFLUENCE ON SALMONID ECOLOGY}

Fish populations and species, their relation to stream structure, and habitat zonation of riparian vegetation, have been the objects of numerous studies (Beschta and Platts 1986; Bilby and Likens 1980; Boussu 1954; Brown 1969; Brown and Krygier 1970; City of Portland 1992C; Cummins 1974; Elser 1968; Meehan 1970; Sedell and Triska 1977; Sullivan et al. 1987; Swanson and Lienkaemper 1978; Swanson et al. 1976; Toole et al. 1983). The decline of physical complexity of forest and stream interactions in the Pacific Northwest was evaluated by Sedell and Luchessa (1981).

Riparian areas are physically dynamic components of the landscape, hosting complex interactions encompassing elements of both aquatic and terrestrial ecosystems (Meehan et al. 1977). Riparian vegetation affects fluvial ecosystems by shading the stream, stabilizing banks, taking up nutrients, contributing organic material, retaining particulate matter during flood events, providing cover, and contributing large organic (woody) debris (Table 2) (Meehan et al. 1977; Moring et al. 1985; Platts 1983). 
TABIE II

RIPARIAN VEGETATION FUNCTIONS

IN RELATION TO A STREAM ECOSYSTEM

(Swanson et al. 1982, 269)

\begin{tabular}{|c|c|c|}
\hline site & Component & Function \\
\hline $\begin{array}{l}\text { Floodplain } \\
\text { Above } \\
\text { channel }\end{array}$ & Canopy and stems & $\begin{array}{l}\text { 1. Shade controls temperature and instream primary } \\
\text { production } \\
\text { 2. Source of large and fine plant detritus } \\
\text { 3. Wildlife habitat }\end{array}$ \\
\hline In channel & $\begin{array}{l}\text { Large debris derived } \\
\text { from riparian } \\
\text { vegetation }\end{array}$ & $\begin{array}{l}\text { 1. Control routing of water and sediment } \\
\text { 2. Shape habitat - pools, riffles, cover } \\
\text { 3. Substrate for biological activity }\end{array}$ \\
\hline Streambanks & Roots & $\begin{array}{l}\text { 1. Increase bank stability } \\
\text { 2. Create overhanging banks - cover } \\
\text { 3. Nutrient uptake from ground and streamwater }\end{array}$ \\
\hline Floodplain & $\begin{array}{l}\text { Stems and low-lying } \\
\text { canopy }\end{array}$ & $\begin{array}{l}\text { 1. Retard movement of sediment, water, and floated } \\
\text { organic debris in flood flows }\end{array}$ \\
\hline
\end{tabular}

\section{Stream Cover}

Riparian vegetation provides elements of shade or shadow, affords cover, protecting salmonids from impact by elements or predators (Binns and Eiserman 1979; Butler and Hawthorne 1968). Salmonids prefer cover overhead such as overhanging vegetation, water turbulence, undercut banks, logs and other woody debris, but also use submerged logs, large rocks, and aquatic and terrestrial vegetation, and objects, such as floating debris and water depth for cover (Butler and Hawthorne 1968; Wesche et al. 1987). 
Cover provides protection from sunlight, disturbance, and predation during all lifestages. Cover proximity is a determining factor in selection of spawning sites and food (Chapman 1966; Helfman 1981). Cover is crucial to spawning Steelhead which may enter freshwater streams long before they spawn (Reiser and Bjornn 1979). Shaded areas of overhanging vegetation are needed to protect juvenile salmonids during the vulnerable rearing stage (Everest and Chapman 1972; Hartman 1965).

\section{Temperature}

Streamside vegetation serves as a thermoregulator, shading the stream, keeping water temperature cool in summer and preventing heat loss in winter (Chapman 1962; Greene 1950; Gray and Edington 1969; Narver 1972; Moring 1975; Moring and Lantz 1974; Platts 1983). Salmon growth rate, timing of migration, maturation, availability of dissolved oxygen, swimming ability, ability to capture and use food, and ability to withstand disease outbreaks, are all watertemperature influenced.

cooler temperatures limit aquatic primary productivity, maintaining dissolved oxygen concentrations reducing stress in salmonids (Whitmore et al. 1960). Research shows temperatures above $64^{\circ} \mathrm{F}$ cause stress for salmonids, with death occurring near $77^{\circ} \mathrm{F}$ (Jobling 1981). Johnson Creek has highly fluctuating summer temperatures often exceeding $70^{\circ} \mathrm{F}$ (City of Portland 1992a). 
Woody Debris

The riparian zone contributes large woody and smaller organic debris which determines physical and bioenergetics of a stream, creating and maintaining salmonid habitat structure and diversity (Anderson and Sedell 1979; Bisson et al. 1987; Heede 1980). Woody debris serves as an important structural element in streams, dissipating stream energy, stabilizing and protecting stream banks, and storing inorganic sediments of sand and silt (Bryant 1983; Everest and Meehan 1981; Harmon et al. 1986). Woody debris serves as a form of sediment storage, creating areas of reduced water velocity allowing sediments to settle out and be removed by higher, more diluting flows, affecting salmonids by filling rearing pools, smothering spawning gravel, and choking aquatic insects inhabiting riffle habitats (Bryant 1985; Heede 1986).

Large woody debris provides channel roughness elements, increases channel heterogeneity through flow direction, turbulence, and velocity alteration which leads to creation of varied habitat types (Everest and Meehan 1981; Harmon et al. 1986; Moore and Gregory 1989). Root wads and trunks decrease the water's mechanical energy (Li and Shen 1973), allowing pools to be scoured, providing cover and habitat for salmon. Smaller logs and root wad accumulations along the banks cause cutoffs, which create backwater pools and eddies, this can help in developing side channels for 
important rearing and wintering habitat (Hartman and Brown 1987).

Channel maintenance by woody debris removal can decrease number, area, and volume of pools while increasing riffle areas and can decrease abundance of yearling salmonids (Bilby 1984; Bryant 1983; Dolloff 1986). Pools are structurally complex serving as refugia during low flow, flood, or seasonal conditions; in summer cool groundwater can create a thermal refuge from warmer stream temperatures, and in winter, warmer groundwater can moderate freezing temperatures (Bilby and Bisson 1987). Flushing events, coupled with the lack of high water refuge habitat as influenced by woody debris, can reduce the number of small fish (EIIis 1992).

Salmonids generally prefer woody debris-influenced habitats in the main channel, near shore, and side channel habitats (Harmon et al. 1986). For example, of the juvenile salmon, Coho prefer cover created or influenced by woody debris in reduced velocity side channels or channel edges (Bryant 1983); juvenile Cutthroat like woody debris in pools, Steelhead prefer riffles (Bisson et al. 1987). Channelization on the lower part of Johnson Creek has increased riffle habitat, which favors Rainbow trout (or juvenile steelhead), while cutthroat trout were more abundant in the upper basin, preferring woody debris (City of Portland 1992c). 
Salmon and their food supply depend on nutrient inputs from the riparian zone (Vannote et al. 1980). Woody debris traps smaller organic matter carried by the water, providing food sources and habitat for salmon (Sedell and Triska 1977). Decaying organic litter forms the base of food chain, becoming food for microbes, which are consumed by aquatic insects (macroinvertebrates), these in turn serve as a principal food item for salmonids.

\section{Food supply}

Salmonid food sources in streams are diverse terrestrial and aquatic insects (macroinvertebrates) originating from the surrounding land and substrate within the stream. The relative importance of macroinvertebrate food supplies vary with stream size, location, riparian vegetation, and season. Depending on the stream, terrestrial or aquatic insects may be the most important food source for juvenile anadromous salmonids (Gregory et al. 1991). Frequent flood events, in addition to pollution, may harm macroinvertebrate populations, and ultimately salmonid food supply, by flushing effects (Reiser et al. 1987). 
Vegetation Rooting

Terrestrial vegetation, rooted in and close to stream channels, stabilizes banks, minimizing soil erosion (Sullivan et al. 1987). With healthy riparian vegetation present, root systems of plants provide streambank stability, allowing some erosion to proceed resulting in undercut banks with overhanging vegetation, providing escape cover for salmon (Meehan et al. 1977). 


\section{PHYSICAL GEOGRAPHY AND SALMONIDS OF} THE JOHNSON CREEK WATERSHED

Energy, in the forms of mechanical, physical, gravitational, and biological forces, gives the Johnson Creek drainage basin a unique character and physically dynamic landscape. Ultimately, land use dictates how the stream channel is shaped and affected (Dunne and Leopold 1978; Schlosser 1991). Natural forces in the Johnson Creek watershed may be attributed to climate, topography, geomorphology, hydrology, and soils. Precipitation and stream flow, thermal cycles, fluvial dynamics of the stream and floodplain, land water interactions, biological interactions, and chemical factors, affect the creek's unique character and its inhabitants, such as salmon.

\section{SALMONIDS IN JOHNSON CREEK}

This thesis considers species from the family Salmonidae, a group of anadromous and freshwater fish ranging across Eurasia and North America. Genus onchorhynchus is represented by five species of trout and salmon in Johnson Creek, referred to collectively as salmonids or salmon (Table 3 ). 
TABLE III

SALMONIDS IN JOHNSON CREEK

\begin{tabular}{|l|l|}
\hline \multicolumn{1}{|c|}{ Species } & \multicolumn{1}{c|}{ Common Name } \\
\hline \hline o. tshawytscha & Chinook salmon \\
\hline o. kisutch & Coho salmon \\
\hline ‥ clarkii & Cutthroat trout \\
\hline ‥ gairdneri & Steelhead salmon \\
\hline ‥ mykiss & Rainbow trout \\
\hline
\end{tabular}

The chinook and coho salmon are anadromous, migrating to and from the open ocean and spawning in fresh water streams, then dying. Steelhead migrate to and from the sea, but not necessarily once. Rainbow trout live their lives wholly in fresh water streams, although they are similar to Steelhead as juveniles. Cutthroat trout can be anadromous, but are permanent residents in Johnson Creek (City of Portland 1992C).

Coho, Steelhead, and Chinook spawn from early fall through late spring in Johnson Creek. There have been reports of two separate runs of adult steelhead observed in Crystal springs Creek (river mile 1.1), one in late November to January, and late March through mid-May (City of Portland 1992c). Chinook and Coho salmon runs occur at about the same time, with the exception of a late summer/early fall run of Chinook. Oregon Department of Environmental Quality 
(1975) reported that high summer temperatures and low flows have made the creek downstream of Gresham (river mile 15) unsuited for salmonids; most are found above Gresham (City of Portland 1990c). Coho and steelhead are believed to migrate beyond Gresham to spawn, while Chinook may stray a couple of miles up the lower creek from the willamette, but there is no record of any higher in the system (City of Portland 1990c). Juvenile fish will stay in the stream one to three years.

Population estimates of fish in the creek are important in determining if sufficient habitat exists for those fish. There is limited information available on the number of wild fish presently using the creek due to the extensive and costly effort involved in determining such numbers. Data does exist from fishery surveys, on which the following is based (City of Portland 1992a). The fish community analysis showed only one coho and one chinook, both found in the lowest 1.1 river mile of Johnson Creek (City of Portland 1992a). In addition, 25 juvenile Rainbow trout were found in the 11 sections sampled. How many of the Rainbow trout were anadromous (steelhead) is indeterminable since as juveniles they are too similar to resident Rainbow trout. No potentially anadromous salmonids (Coho, Chinook, or Rainbow/steelhead adults or juvenile) were found above river mile 9.2. Salmon spawning surveys conducted for a total of seven weeks in the spring and fall of 1992, reported only 
three live steelhead, as well as three Chinook and one Steelhead carcass, all below river mile 5.7 (City of Portland 1992a). In addition residents reported seeing six Steelhead spawning around river mile 2.9 (City of Portland 1992a). These results suggest that the wild populations of salmon using Johnson creek are critically low in number, they use the lower creek, contrary to earlier reports (City of Portland 1990c; Oregon Department of Environmental Quality 1975; Oregon Department of Fish and wildlife 1989, 1990), and that suitable and available habitat is unutilized.

\section{LOCATION}

The 54-square mile Johnson Creek basin is sandwiched between four larger rivers, the Columbia, Sandy, willamette, and Clackamas (Figure 1). Johnson Creek has the greatest average discharge and the largest drainage basin $(34,500$ acres) of any Portland stream (City of Portland 1987b). Johnson Creek originates in a swale 24.8 miles east of the Willamette River. Headwater elevation is approximately 730 feet above sea level, depending on time of year and amount of precipitation. Average stream fall is 29.3 feet per mile (Figure 3 ). The basin is 18 miles long and averages 3 miles wide (Seltzer 1983). Stream depths range from a few inches in some riffles to eight feet in deep, channelized sections. 


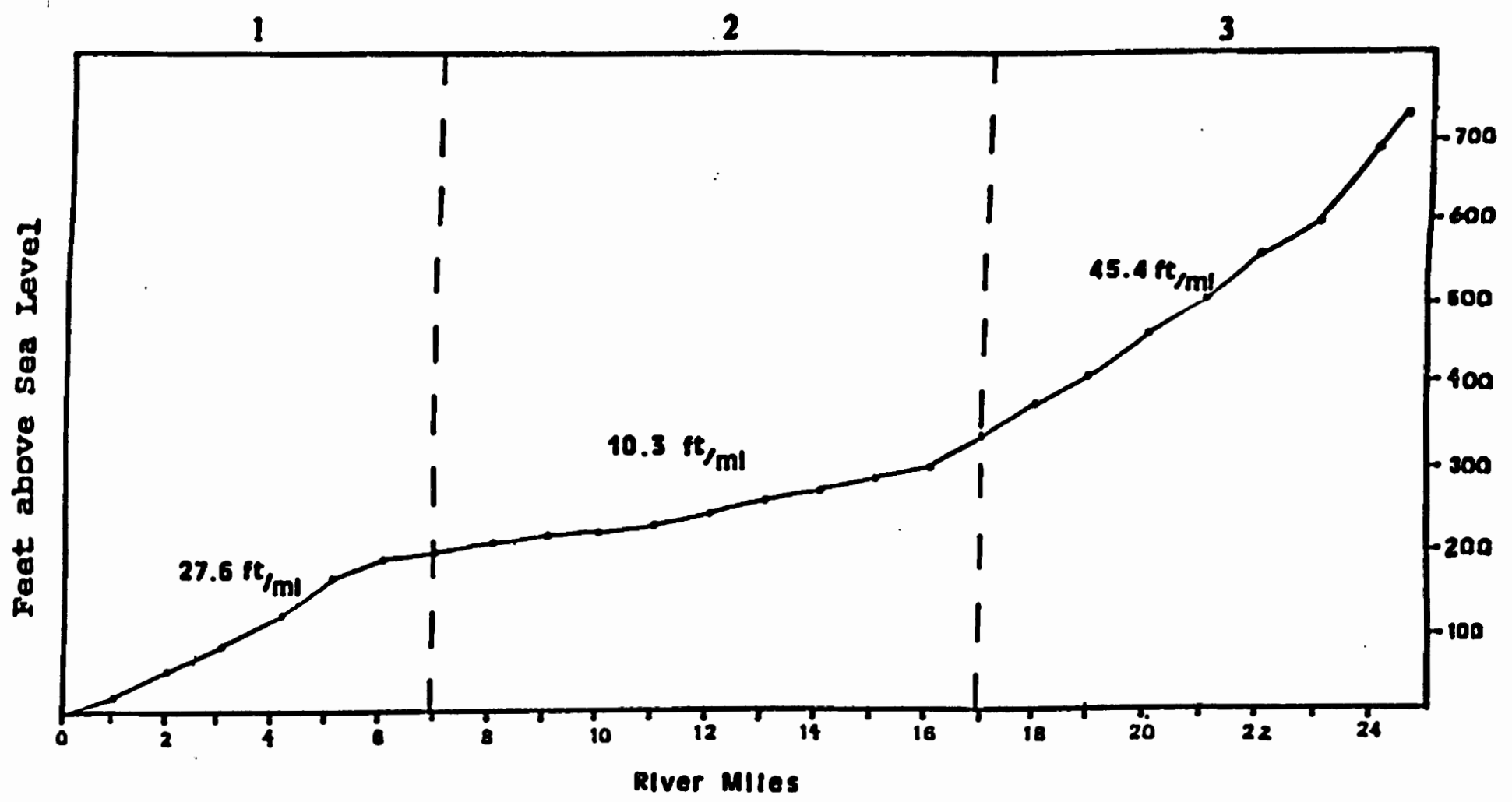

Fiqure 3. Stream profile of Johnson Creek (Adapted from U.S. Geological Survey Quadrangles for Sandy (1985); Lake Oswego, Gladstone, and Damascus (1984). 
Average depth at base (summer) flow is estimated to be less than 1 foot.

\section{CLIMATE}

The Johnson Creek watershed experiences a moderately humid, temperate climate. of the total annual rainfall, around 80 percent occurs in the eight months from october to May (Clement 1984); this usually occurs as a constant drizzle, which results in greater infiltration and less direct runoff.

\section{GEOLOGY, GEOMORPHOLOGY, AND LANDFORMS}

Johnson Creek basin is situated in the Puget-Willamette Trough, a major geomorphic anticline (Clement 1984) intersecting three distinct physiographic subareas with unique topography, the Kelso Slope, Boring Lava Hills, and Portland Terraces (Figure 4). Surficially, the Johnson Creek watershed is geologically recent. Comprised of several rock units, it is underlain by the impervious Columbia River Basalt (Figure 5).

Johnson creek is an inverted basin with finer bed materials in the upper reaches with coarse particles in the lower reaches. Soil types and land use in the catchment contribute to the inverted character. The higher input of sediment from land use in the upper basin augments the finer substrate materials in the upper basin. creek banks are 


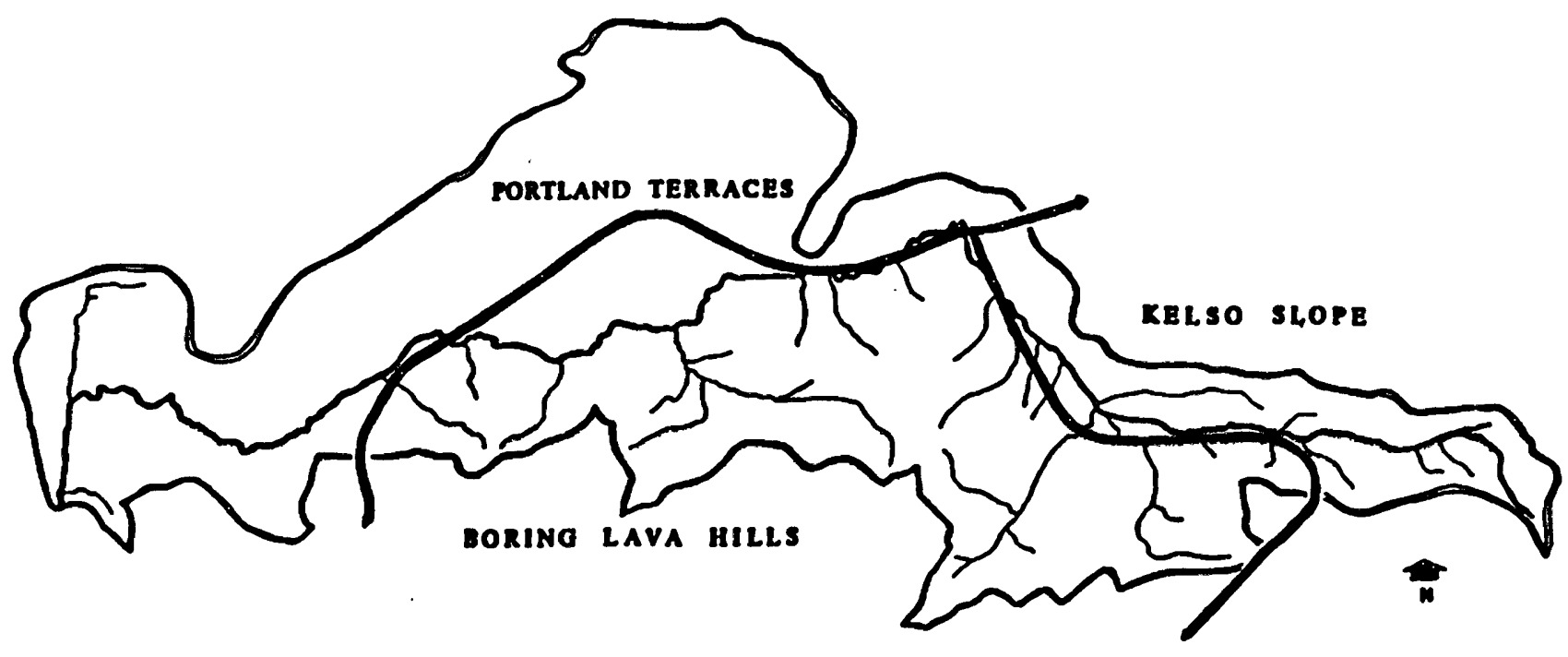

Figure 4: The three physiographic regions in the Johnson Creek basin. The dark line indicates the region divisions (Adapted from Hogenson and Foxworthy, 1965). 


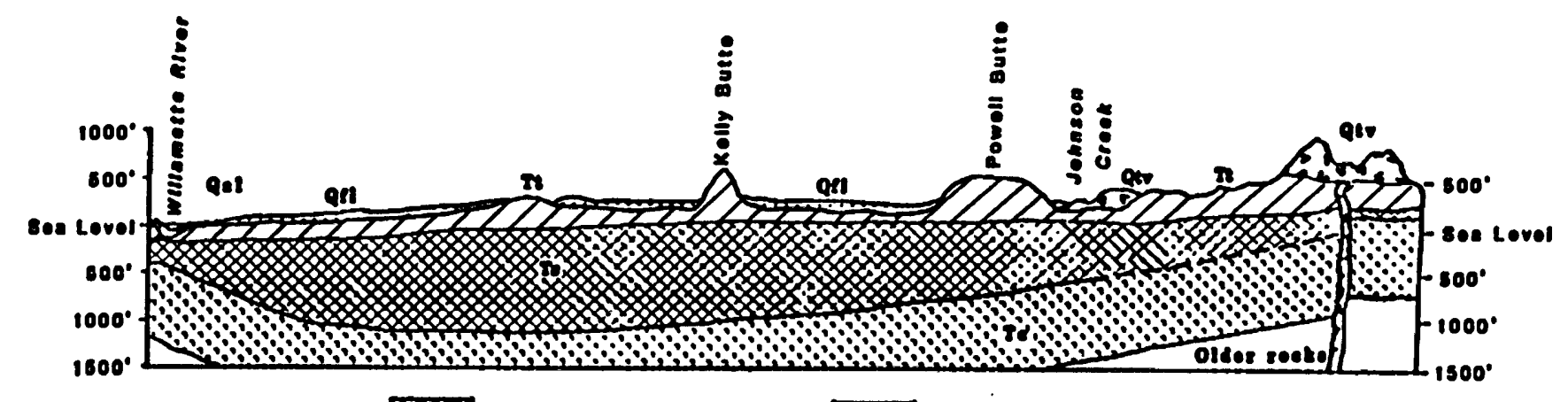

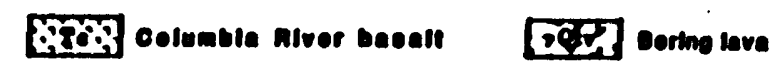

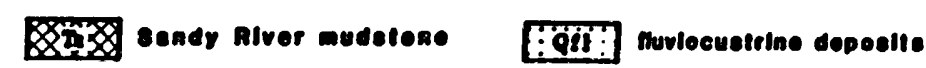

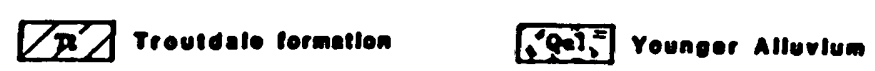

Figure 5. Underlying geology of the Johnson Creek basin (Adapted from Clement 1984,38 ). 
composed of deposited alluvium and sediments which supports vigorous vegetative growth.

\section{SOILS}

Quality and texture of the soils are primarily a function of climate and geology. These in turn influence vegetation which in turn affects sediment and water delivery into stream. Most soils in the Johnson creek basin formed after the Missoula floods abraded the landscape (U.S. Soil Conservation Service 1982, 1983). The eastern end of the Johnson Creek drainage is dominated by well-drained to moderately well-drained soils. From Gresham westward, and north of the creek, large areas have been altered by grading, cutting, and filling as deep as 30 inches. About 15 percent of the original soils in this area are undisturbed, with around 30 percent of the complex covered by disturbed Multnomah soils formed in stratified cobble and gravel-type alluvium. South of the creek the soils have moderate to poor infiltration rates. This area is also dense in vegetation, aiding drainage and by slowing runoff. The remainder of this part of the watershed is typically urbanized land dominated by impervious surfaces.

In combination with sparse vegetative cover of agricultural areas, soils in the eastern watershed have medium to high erosion potential, contributing large amounts 
of sediment and agrochemicals to the creek (City of Portland 1992C; U.S. Geological Survey 1988).

GROUNDWATER

Groundwater in the east Portland area has been extensively examined by Hogenson and Foxworthy (1965). Groundwater is an important physical influence on Johnson Creek because it feeds the creek during the usually dry summer season. Groundwater in the Johnson Creek basin is discharged naturally through springs on the land surface or into the creek from seeps exiting through a permeable stratum. Artificial withdrawal occurs by wells or drains. The groundwater bodies in the basin receive natural recharge by infiltration from surface precipitation. The western portion of the basin to the north of the creek has a considerable percolation sump system which drains storm runoff into the underlying porous soils and alluvium (City of Portland 1985; City of Portland 1987a). Groundwater in the Johnson Creek drainage has been utilized for domestic, stock and public water supplies, for irrigation, and for industrial uses.

SURFACE WATERS

Johnson Creek is the largest of five small streams that drain the east side of the Portland area. Johnson Creek 
displays a typical regional hydrograph with low summer flows graduating into higher winter flows (Figure 6).

Mean annual stream flow is 54 cubic feet per second (cfs), maximum annual stream flow is $91 \mathrm{cfs}$, and minimum annual stream flow is 15 cfs (U.S. Geological Survey 1990a). Johnson Creek has numerous tributaries, principally from the south. Crystal Springs Creek (river mile 1.15) Kelley Creek (river mile 10.9) and Anderson Creek (river mile 18.75), are the largest perennial tributaries, but there are many small draws and valleys which contribute surface water to the creek intermittently.

In the sellwood district (river mile 1.1 to river mile 2) springs issue at the foot of steep terrace scarps, feeding Crystal springs Creek and giving it consistent flows and temperatures year round. These springs also discharge to the lower reach of Johnson Creek.

\section{HISTORICAL LAND USE}

The historical development and land use activity in the Johnson creek basin has been documented extensively (Metropolitan Service District 1981; Seltzer 1983) and the following is derived principally from these documents.

Artifacts indicated that Native Americans were the original inhabitants of the area. Johnson Creek however, 


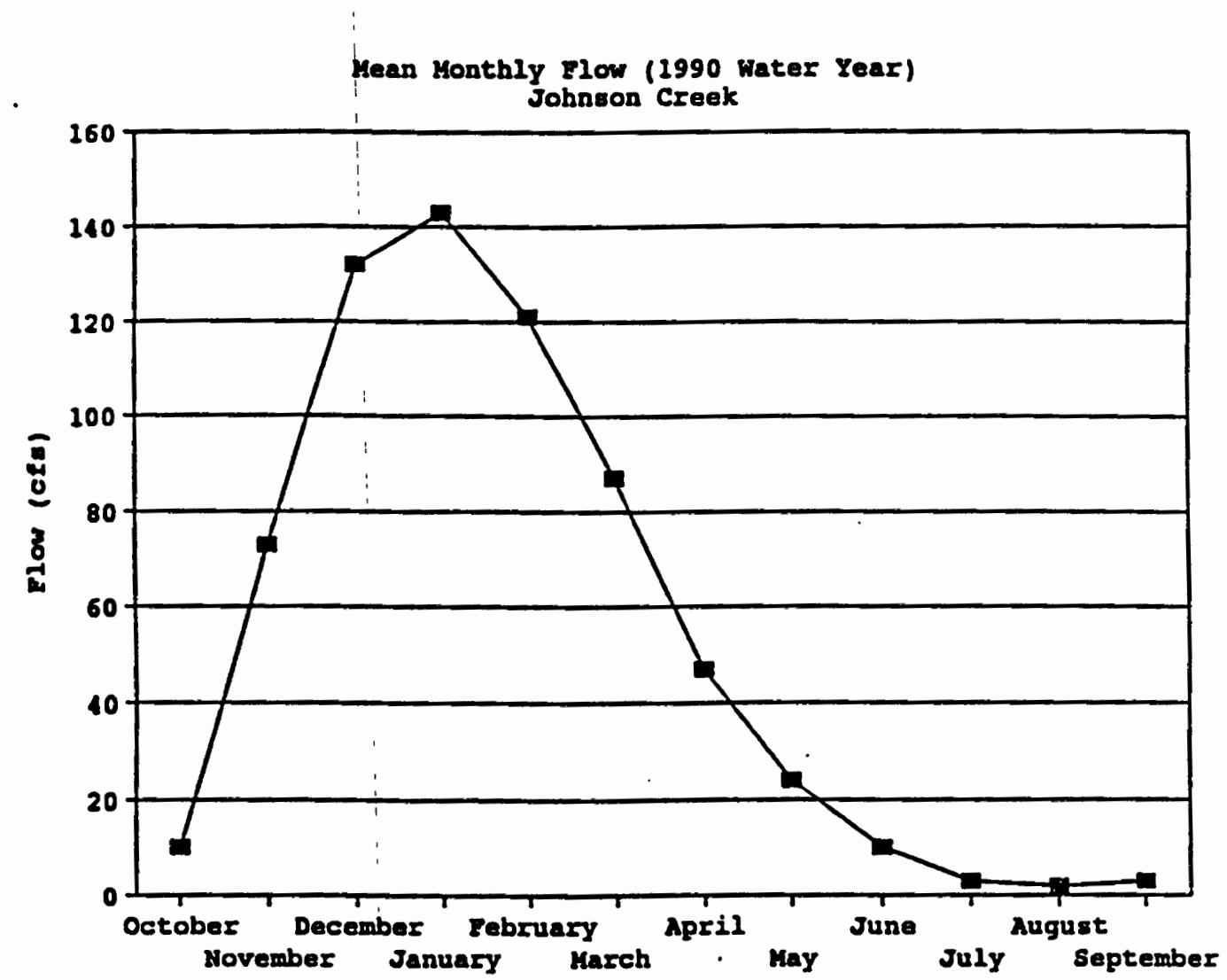

Figure 6. Hydrograph of Johnson Creek depicting average monthly flow (U.S. Geological Survey 1990a). 
derives its name from a Maryland family that settled on the south side of the creek at the base of Mt. Scott, river mile 7.5, in 1847. The timber industry dominated the region's economy until the turn of the century. When the timber was gone, the Johnson Creek floodplain was settled by dairymen in the east and truck farmers in the middle reach. An interurban electric rail line ran to Portland. Roads in the area were not improved until the 1920 s and 1930s. The most extensive development occurred in the middle reach of Johnson Creek which had the broadest floodplain. Log holding ponds and hydropower development were some of the early uses of the creek.

The relatively flat floodplain was ideal for agriculture, being inundated by annual flood events depositing silt-rich sediments, providing natural fertilization. Farmers increased the creek meanders and inserted several sharp 180 degree bends to expand the floodplain. By the 1930s the population, development and urbanization were increasing in the basin. With farmers selling to developers, flooding became a problem instead of a natural advantage for floodplain residents. The Works Progress Administration began channel alterations to address flooding problems from 1933 to 1936.

The Works Progress Administration projects involved channel excavation and rip-rap, beginning at the mouth and continuing upstream for 15 miles. The stream was dug down 
to a 15 foot depth, and rip-rapped by hand with large rectangular stones to protect against erosion. A waterfall along with a channel split, was constructed at 45 th street, as was a fish ladder. The bends the farmers put in were not altered to return the stream channel to its original course, but rather were graded with 45 degree banks, all fully riprapped. This occurred before the major housing booms in the area after World War II. By 1950, the floodplain farmers subdivided their land, selling to home builders. The eastern basin, changed from dairy farms to truck farms, then to nursery crops in the 1950s and 1960s. Small rural hamlets and residential communities eventually grew into the diverse urban complex that is now the east side of the Portland metropolitan area. This urbanization impacted the riparian zone and the salmonid habitat. Urbanization, including residential, commercial, agricultural development, have increased throughout the corridor since then. Poor riparian conditions on Johnson Creek have contributed to increased erosion, land loss, washed out banks, and degraded habitat conditions. When the Johnson Creek basin was first colonized by white settlers in the early to mid-1800s the area had extensive coniferous forests supporting wildlife common to the region, including bear, elk, eagles, and wolves, with plenty of wild salmon in Johnson Creek (Seltzer 1983). 
Today the Johnson Creek watershed is a changing mosaic of land use and vegetation types. Development and farming operations have displaced or depleted natural vegetation patterns, leaving a disparate mixture of agricultural lands, urban and suburban landscapes, upland forests, wetlands and riparian habitats. The riparian vegetation in the floodplain and in the immediate riparian strip bordering the creek is typical of such altered vegetational landscapes. Areas of natural riparian stream sections exist and provide a basis for comparison to urbanized ones.

\section{EFFECTS OF URBANIZATION}

In the Johnson Creek basin as in any basin, urbanization processes affect streams in three ways: physical, chemical, and biological. Chemical effects include water quality changes due to urban runoff and the alteration of the natural chemical cycle. Biological changes include decreased species diversity and decreased abundance. Physical effects due to urbanization are manifested in a changing hydrograph with regard to stormwater runoff-rainfall relationships affecting flooding, increased conveyance and capacity of suspended and bedload sediment, human and natural channel modifications to accommodate the water and sediment, and thermal regime changes. All these processes ultimately affect the riparian and instream habitat for fish. 
Hydrologic changes due to population increase and subsequent urbanization have increased runoff and flooding, but most noticeably have changed the cover and surficial character of the basin's landscape. Greater areas are covered with impermeable surfaces such as roofs, driveways, streets, parking lots, sidewalks, which decrease infiltration and increase the quantity of runoff. Extensive channelization is a phenomenon of urbanizing areas. Channelization has altered 15 miles of Johnson Creek's floodplain and instream environment. The stream channel has been dug out and armored to accommodate flood waters and sediment load. The resulting narrower channel, combined with swifter and deeper flows, reduces aquatic habitat diversity and species richness.

Channelization projects change the instream environment for fish and cause channel instability. Streams are in dynamic equilibrium if their energy levels are such that sediment loads entering a stream reach equal those leaving it (Leopold et al. 1964). When a stream's dynamic equilibrium is disrupted, harsher environmental conditions are imposed on salmon and stream biota. The effects of disequilibrium include increased bank erosion, and bed agradation and degradation. A channel alters its cross section toward a form and size commensurate with the discharge experienced in the reach, or toward dimensions approximating the original or unaltered stream of its 
drainage area. However, the more urbanization and development that proceeds the more the stream will change, in response to increased carrying capacity of water, sediments, and nutrients (Dunne and Leopold 1978).

The predominance of agriculture in the upper basin increases sediment and nutrient loads in the creek. Land cleared for agriculture and grazing reduces streamside cover and increase sediment-laden runoff. In addition, applications of commercial fertilizers and pesticides eventually enter the stream. Sediment is carried by the increased runoff over the bare soil in nursery fields. Where cattle and horses have access to the streambank, trampling increases erosion and contributes to a reduction in bank stability. Stream access by residents increases awareness and cognizance of the resource, but streambank and instream trampling, and garbage become problems. Fish are also more vulnerable with increased access to the creek and the elimination of habitat diversity and cover with riparian vegetation losses.

Yard maintenance by private landowners along Johnson creek ranges from leaving the riparian vegetation in its natural state to complete denudement including herbicide treatments, pruning, and mowing. Often residents effect changes in the stream through root wads, downed trees, and organic debris removal, rip-rap, fill, garbage and yard debris dumping. Intensive yard landscaping can reduce cover 
and habitat diversity, allow more direct sunlight on the creek, increase erosion by bank destabilization, increase sediment in the water, and serve as a source of toxic substance introduction.

\section{WATER QUALITY}

Water and sediment quality are severely compromised in Johnson Creek as a direct result of urbanization. Water quality is limited by runoff from the various land uses contributing concentrations of organic pollutants, bacteria, heavy metals, polychlorinated biphenyls, and agricultural chemicals, including some residuals such as DDT and its metabolites (U.S. Geological Survey 1989, 1991). Sediments and fecal contamination are two major sources of pollution. Sediments come from construction, agricultural activities, urban runoff, channel scour and streambank erosion. Fecal contamination enters the creek from failing septic systems and cesspools. This is more evident during high flow winter months; whereas in summer, groundwater contributes to high concentrations of organic pollutants. Other water quality limiting events include periodic discharges and spills of unknown origin, many resulting in fish kills (City of Portland 1992c). The City of Portland (1990b) has identified 42 nonpoint polluting sources, all industrial facilities in the western basin. There are 142 point source storm outfalls owned by municipalities (City of portland 
inventory 1990b). In addition, there are three potential Environmental Protection Agency Superfund sites in the basin (Plate 2) (City of Portland 1992b).

With the high population density, sewerage has been a concern along Johnson Creek and within the basin for a number of years. The creek has a major sewer trunk paralleling the creek or lying under the streambed from 82nd Street to Johnson Creek Park. The City of Portland (1984, 1987a) has extensive sewer improvement plans for the basin. Septic tanks, storm overflows, and suspected main trunk leaks contribute to the poor water quality along the length of the stream corridor (City of Portland 1979; Clackamas County 1989). During the summer low flows, groundwater influxes are predominant; in winter, high flows with precipitation and runoff dominate. During high flow periods there is nutrient loading, while during low flows there is septic tank leakage (City of Portland 1979). Periodic fecal coliform counts at some sites exceeded state water quality standards restricting water contact sports (City of Portland 1992C).

A combination of land use, soil characteristics, and climate have contributed to the high erosion rates and sediment content in Johnson Creek. Soil erosion has caused historical problems in the watershed. Sediment transport to the creek has caused high suspended sediment, turbidity, and excessive intergravel and substrate sediments (City of 
Portland 1990b, 1992c; U.S Geological Survey 1989, 1991). Included in the sediments eroding into the creek are excessive nutrients, pesticides, fertilizers, industrial contaminants, and urban runoff. This combination forms a hazard to the stream's aquatic life. Activities in the watershed, such as land development and construction, heighten the erosion problems. Farming practices on the nurseries and farms that predominate the eastern watershed have contributed to the erosion. Often there is little if any effort made to decrease sediment yield to the creek. Construction and other activities that expose bare soil increase erosion with precipitation. By trapping and stabilizing runoff, riparian vegetation plays an important role in preventing excessive sediment loading.

Urbanization and agricultural development along Johnson Creek have historically altered the riparian-influenced salmonid habitat. The cumulative effect of channel modifications, land development and property maintenance in the basin have increased runoff and flooding, reducing and homogenizing the amount of physical habitat available to salmon in Johnson Creek. Decreased water quality from toxic substance introduction, and sediment and nutrient loading, has played a significant role in compounding stressful environmental conditions for salmon. 
CHAPTER IV

\section{METHODOLOGY}

This study was undertaken to provide an assessment of current conditions and potential influences of urbanization on riparian-influenced salmonid habitat features. The assessment consisted of a stream survey assessing five riparian vegetation attributes for contributions to salmonid habitat. The results provide a basic understanding to the extent of Johnson Creek's riparian vegetation's interaction with salmon habitat.

The methodology used for this stream survey was adapted from the U.S. Forest Service stream inventory guidelines (1990). This methodology is normally used on natural streams that have suffered less human impact than an urban stream such as Johnson Creek. The Forest Service guidelines call for detailed data including stream, geomorphic, and riparian attributes, and the use of two surveyors. The methodology consists of gathering data on riparian and aquatic ecosystem conditions on a basin-wide scale: watershed and stream geomorphic features, water quality and flow, fish, macroinvertebrates, historical land use, riparian attributes, stream substrate, and physical stream habitat types. This methodology is costly and time 
consuming. Adaptions of the methodology were made to facilitate the observations of one independent observer concentrating solely on riparian-influenced salmonid habitat features. The quality and quantity of these five basic riparian-influenced salmonid habitat features were identified and measured in sample sections along Johnson creek. These features were chosen because they are recognized as important habitat components (Meehan et al. 1977). Quality of a habitat feature was determined by assessing the feature's contribution to salmonid habitat. Prior to the stream survey the watershed was divided into three reaches for analysis based on overall land use and physical geography. The three reaches were chosen based on analysis of topographical and land use maps, and high altitude photographic images. In viewing aerial images and maps of the basin and creek corridor, three distinct regions of the Johnson Creek basin stand out: the heavily urbanized western reach, the residential/rural middle reach, and the agricultural eastern reach. Criteria for comparing the three reaches were: degree of urbanization, type of land use, amount of natural area remaining, physiography, topography, channel geometry, hydrology, geology, soils, amount of precipitation, degree of channel alterations, and stream character. The data was found in maps, images, publications, and previous studies on Johnson Creek and the southeast portland area. 
In each reach three sample sections were chosen, representative of the differing land uses and degrees of urbanization, and riparian corridor conditions represented in the reach, including easy access to the creek (Table 4). Each sampled section in turn consisted of 100 foot subsections, measured alternately by tape and ocular estimation. The stream survey of all nine sections was performed by walking upstream while locating habitat features. When a particular feature was identified, the extent of influence exerted on the stream in relation to salmonid habitat, was recorded.

The five riparian features (or types) were, overhead cover or enclosure of the stream, overhanging vegetation, undercut banks, and large and small root wads and woody debris. The presence of riparian vegetation influencing the stream was quantified in each 100-foot subsection by measurement or ocular estimation.

As a relative measure of importance, contribution to salmonid habitat was determined by measuring linear feet per mile of undercut banks, and number of root wads and woody debris per mile. Overhead enclosure was ocularly estimated as to what percentage of the stream it covered. Overhanging vegetation was estimated as to what percentage of the creek banks was overhung. 
TABLE IV

GENERAL LAND USE BY SAMPLE SECTION IN JOHNSON CREEK CORRIDOR

\begin{tabular}{|c|l|}
\hline \hline Sample Section & \multicolumn{1}{|c|}{ General Land Use } \\
\hline IA & Commercial, light industrial \\
\hline IB & Natural, residential \\
\hline IC & $\begin{array}{l}\text { Residential, light industrial, } \\
\text { commercial }\end{array}$ \\
\hline 2A & Residential, commercial, natural \\
\hline 2B & Rural residential, small farms \\
\hline 2C & Natural, residential \\
\hline 3A & Natural, rural residential \\
\hline 3B & $\begin{array}{l}\text { Rural residential, small farms, } \\
\text { nurseries }\end{array}$ \\
\hline 3C & Nurseries, rural residential \\
\hline
\end{tabular}

Overhead enclosure included streamside and overstory contribution to stream shading more than two feet above the water (Figure 7). Overhanging vegetation was defined as vegetation hanging over the banks of the stream, less than two feet above the water, which would provide direct cover for salmon. Overhead enclosure and overhanging vegetation estimates were based on a maximum of 100 percent, using five percent increments. 


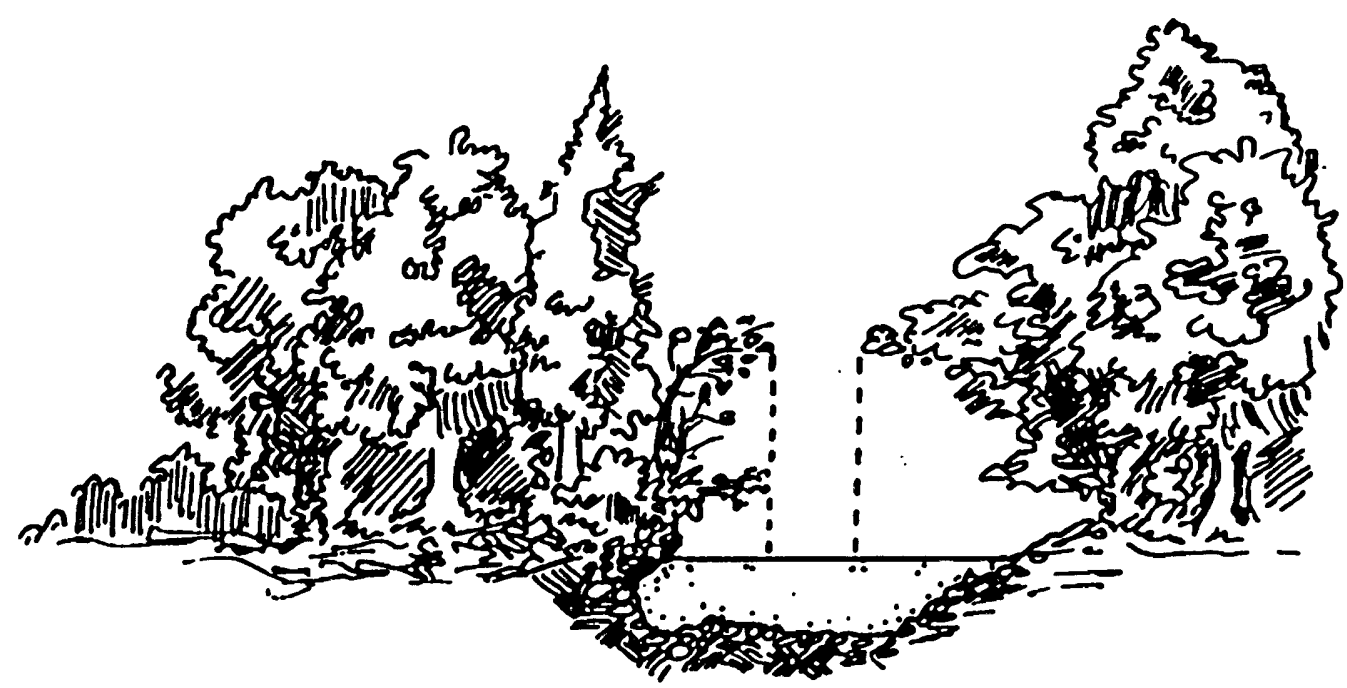

Fiqure 7. Stream overhead enclosure. The dotted line indicates the limit of stream shading when the sun is directly overhead. 
Undercut banks can be a feature of a stable streambank where the current has carved out a little cliff or cave, recessed by six inches or more, under, or at the water surface (Figure 8). The linear distance of the undercut bank along the stream was measured in one foot increments.

Root wads are the root balls or root tangles that overhang stream banks by six inches or more, providing direct overhead cover (Figure 9). A large root wad is three feet or greater in length and overhangs the stream by more than one foot. A small root wad is less than three feet long and overhangs the creek by less than one foot. occurrences of large and small root wads were counted. Woody debris is defined as tree trunks or limbs that have fallen into, or are on the banks overhanging the stream, which provide cover and habitat (Figure 10). Woody debris is in the organic debris category which also includes leaves, bark, sticks, and twigs. Organic debris is important for stream ecology, but provides little habitat for salmonids. Large woody debris is defined as six inches or more in diameter and longer than 6 feet, with small woody debris being between one and six inches in diameter and between six feet and two feet long.

The survey on the nine sections was made in February 1993. Dormant vegetation allowed for easier access along the stream length, and minimally impaired vision of stream habitat features, both above and below the water. There 


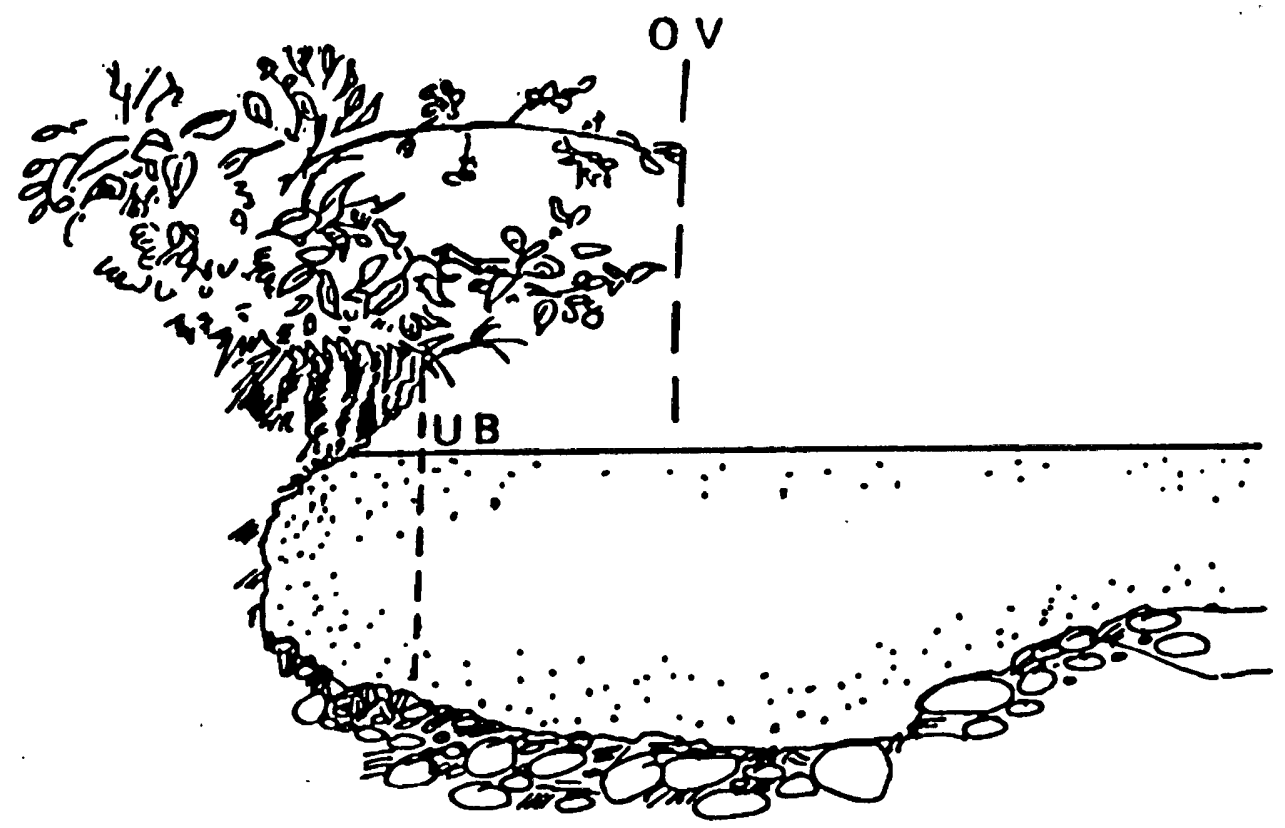

Figure 8. Overhanging vegetation (OV) and an undercut bank (UB). The dotted lines indicate how far the feature overhangs the water. 


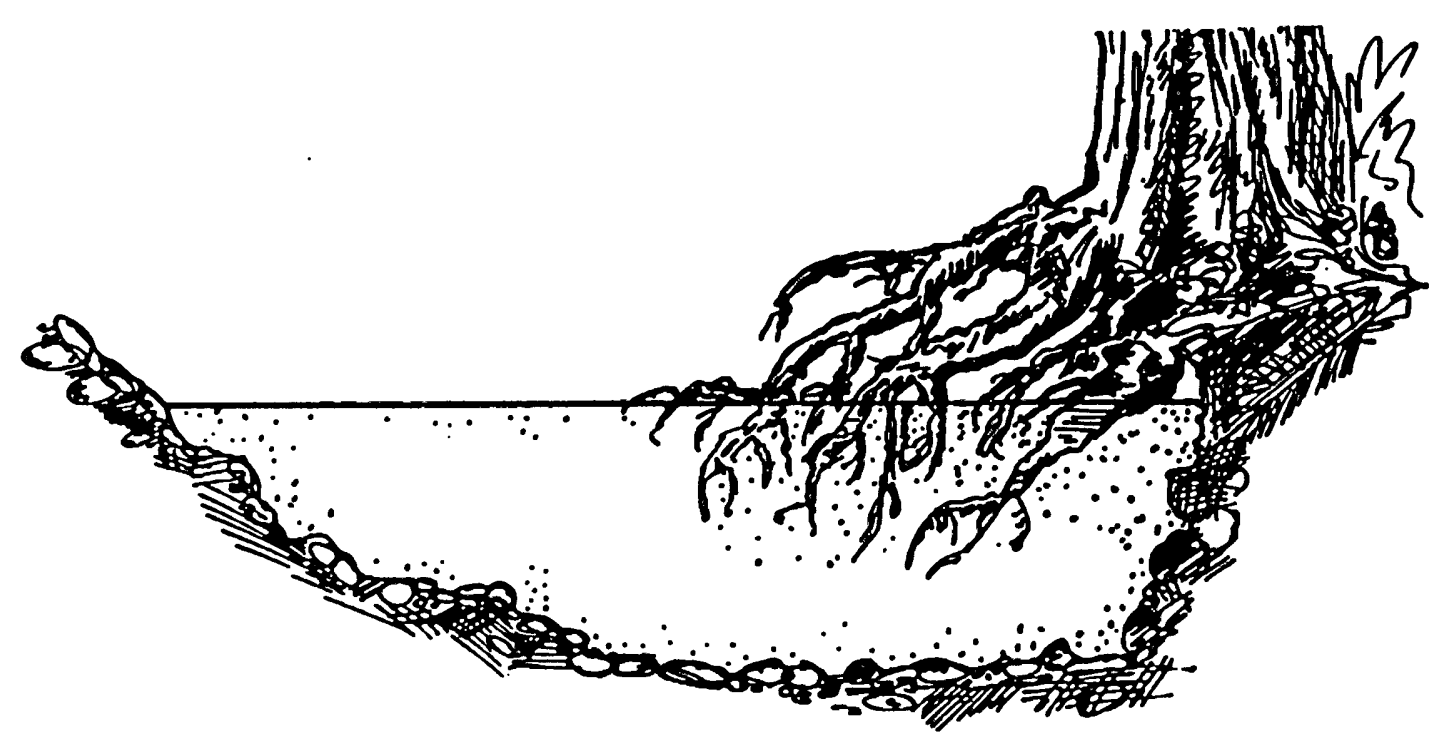

Figure 9. Root wads are the root networks of trees. They can be from a live or dead tree. 


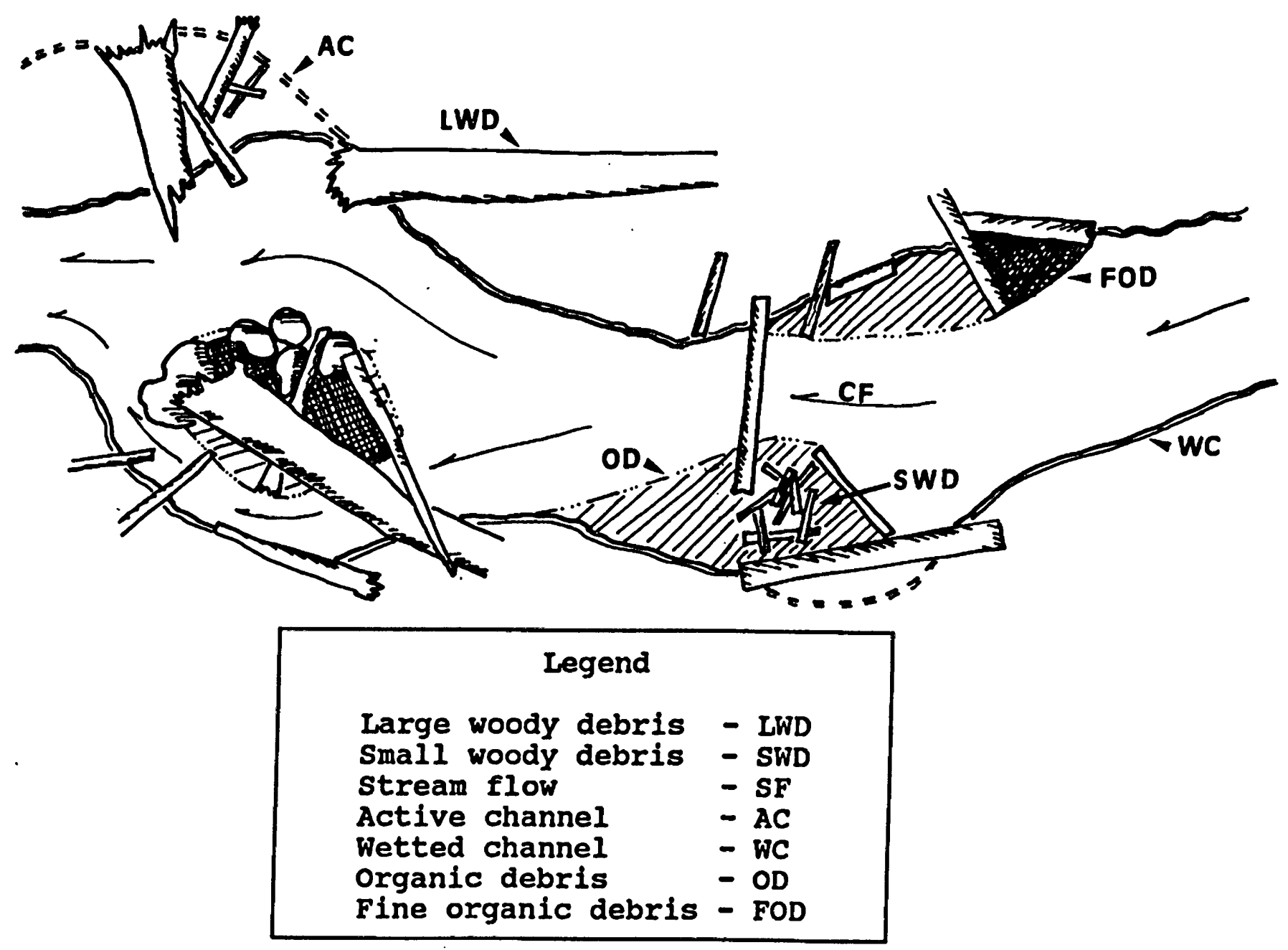

Fiqure 10. A stream channel with large and small woody debris consisting of dead or downed trees, limbs, or trunks of trees lying in the channel creating instream habitat diversity. 
were 22.6 miles of suitable channel habitat, of which 12.4 miles was surveyed. The last 2.2 miles of the $24.8 \mathrm{mile}$ stream channel were too shallow and intermittent in flow to be suitable for salmonids.

An average measurement per mile of each of the habitat features was calculated for the sections and the three reaches. Summary tables for each reach were generated giving the total and average amount of each feature, with a parameter average calculated for each reach. 


\section{CHAPTER V}

\section{RESULTS}

Results of the stream survey indicate that urbanization in the watershed has impacted the creek in different ways. Along the creek, areas of viable riparian habitat as well as areas of poor habitat were found in the nine sections sampled (Plate 3 ). Results showed an increase in salmonid habitat where there was little riparian alteration or impact, and a corresponding decrease of habitat where there was extensive channelization, armoring, and urbanization.

\section{REACH 1}

Reach 1 has the greatest extent of urban residential neighborhoods, industry, and commercial development along Johnson creek. The reach has largely been channelized, but contains an important riparian area.

At its mouth at the willamette River, Johnson Creek is 30 feet wide and flows through a primarily commercial industrial area. Upstream of river mile 2, the creek character changes abruptly as the creek flows through the mouth of the "gorge" or Johnson Creek Canyon. This natural area, lying in Section A, was created as consequence of downcutting and scouring during Pleistocene flooding 
(Hogenson and Foxworthy 1965). At this point the creek width is 20 to 25 feet. Further upstream to river mile seven, the corridor is residential with some commercial and light industrial, and the creek width varies from 15 to 25 feet wide. The results of the stream survey of Reach 1 are presented in Table 5. Abbreviations for the different riparian-influenced salmonid habitat features were used in the tables: overhead enclosure (OE), overhanging vegetation (OV), undercut banks (UB), small root wads (RW-S), large root wads $(R W-I)$, small woody debris (WD-S), and large woody debris (WD-L).

TABLE V

RESULTS OF SURVEY ON REACH 1

\begin{tabular}{|c|c|r|r|r|r|r|r|r|}
\hline Section & $\begin{array}{c}\text { Distance } \\
\text { (mi) }\end{array}$ & $\begin{array}{c}\text { OE } \\
(8)\end{array}$ & $\begin{array}{c}\text { OV } \\
(8)\end{array}$ & $\begin{array}{c}\text { UB } \\
(\mathrm{ft} / \mathrm{mi})\end{array}$ & $\begin{array}{c}\text { RW-S } \\
(\# / \mathrm{mi})\end{array}$ & $\begin{array}{c}\text { RW-I } \\
(\# / \mathrm{mi})\end{array}$ & $\begin{array}{c}\text { WD-S } \\
(\# / \mathrm{mi})\end{array}$ & $\begin{array}{c}\text { WD-I } \\
(\# / \mathrm{mi})\end{array}$ \\
\hline IA & 1.09 & 45.8 & 8.8 & 0.0 & 11.0 & 0.9 & 1.8 & 1.8 \\
\hline IB & 1.15 & 88.3 & 47.1 & 330.4 & 19.1 & 9.6 & 60.0 & 25.2 \\
\hline $1 \mathrm{C}$ & 1.00 & 53.4 & 27.9 & 50.0 & 15.0 & 1.0 & 12.0 & 3.0 \\
\hline Total & 3.24 & 187.4 & 83.8 & 380.4 & 45.1 & 11.5 & 73.8 & 30.1 \\
\hline Average & 1.08 & 62.5 & 27.9 & 126.8 & 15.0 & 3.8 & 24.6 & 10.0 \\
\hline
\end{tabular}

\section{Section 1A}

Section $A$ is the most developed area of the corridor, with light industrial and commercial areas, office complexes, and a waste water treatment plant. The high degree of urbanization has caused the least amount of riparian-influenced habitat along the creek, with little overhead enclosure and overhanging vegetation. 
The channel has been well armored so there is little riparian vegetation offering habitat, other than cover from overhead enclosure and overhanging vegetation. Root wads and woody debris are low in occurrence, whereas undercut banks are eliminated in armored areas.

Some businesses along the stream have pursued an active riparian management policy, either leaving natural vegetation or landscaping for riparian habitat. For example, the Mill End store, located at river mile one, diverts stormwater runoff from parking lots away from the creek, and plants trees in the riparian area. Other property owners have either removed all or most vegetation, allowing no stream shading or overhanging vegetation. This is the case of the parking lot directly across the creek from the Mill End store. Lack of instream debris in this section is probably a result of reduced riparian vegetation, and the increased capacity of flood water's ability to remove debris. Where trees grow along the natural banks, some have developed strong armoring and protective root wad complexes, but most are so flush to the bank that they provide no cover for fish. Indirectly, these armoring root wads can provide benefits to habitat quality by protecting the streambank from erosion.

In this lower section, large instream rocks provide cover by creating turbulence and holding areas. Discarded debris such as large sheets of stiff plastic, boxes, 
pallets, plywood, and tires also provide cover and habitat diversity. The few tributaries that enter Johnson Creek in Reach 1 are piped and culverted.

Section A of Reach 1 has been heavily impacted by channelization efforts and streamside riparian manipulations for flood control, and had little riparian-influenced salmonid habitat.

\section{Section 1B}

section $1 \mathrm{~B}$ is the least disturbed and most topographically constrained section of the creek. The Tideman Johnson Park is located in the eastern canyon and there are few houses. The steep sides of the canyon make development difficult and have afforded a heavy forest growth. The riparian and upslope forest is well developed with a conifer and deciduous mix. The stream is almost wholly enclosed overhead. Numerous root wads and woody debris complexes create diverse habitat. Width ranges from eight to 35 feet wide, with pools up to four feet deep, These have been formed by the effects of stream flow, root wads and woody debris. There is bank armoring going into and coming out of the canyon, but none in the canyon itself. The armoring often has steps to residences, affording access to the creek.

The stream splits into two channels in one place in the canyon. Undercuts in section 1B recede up to two feet beneath the banks, providing cover for fish. The unmanaged, 
dense, mid- to late-successional forest contributes large pieces of woody debris and root wads to the stream. Some are downed trees three feet in diameter. The stream habitat is complex and diverse due to the natural state of the stream. Upon exiting the narrowest part of the canyon, the stream flows into a residential area where creekside vegetation manipulations increase. Here the creek is eight to 15 feet wide.

Section 1B has considerable riparian-influenced salmonid habitat features due to the long stretch of no riparian disturbance. As residential yard landscaping increases upstream of the canyon, riparian-influenced salmonid habitat declines.

\section{Section 1C}

In section 1C the creek widens to 25 feet, and winds its way through residential areas flanked by yards, small industry and commercial businesses. Here, Johnson Creek is buffered from development to the north by the springwater Trail Corridor.

A homogenous habitat has been created by armoring the banks, and to some degree by yard maintenance. Himalayan blackberries comprise most of the overhanging vegetation on the stream banks. Larger trees with their associated woody debris and root wads are mostly absent from this stretch. Numerous boulders in some areas provide cover and habitat diversity. Armoring has limited bank undercutting. Where 
the channel is not armored, it is confined to a deep, incised trough, with steep banks and overhanging vegetation. Even though this section has had extensive channelization, the channel has not received the needed maintenance to accommodate the flood waters for which it was designed. In some areas, where the gradient is low, a considerable amount of bedload has accumulated, causing channel braiding, small island formation, allowing grasses to take hold midstream, increasing habitat diversity.

The degree of yard and streambank maintenance varies. Some property owners tend yards to the edge of the armoring at the top of the bank, while others leave streambanks with a dense growth of trees, bushes, and shrubs. Yard debris, such as grass and bush clippings, were found dumped into the stream. Lack of channel maintenance has lead to greater instream habitat diversity. Steps have been placed in the armoring down to the creek from the older residences. The armoring, where the seams are still tight, does not allow vegetative growth on the stream banks. The chinks and cracks in the seams of the large stones have accumulated organic matter deposited by the running waters allowing vegetation to take root. This, in addition to bank slumping, causes some of the steep channel sides to support vigorous growth where untended by the residents. The lack of channel maintenance leading to sediment and gravel deposition, has created greater instream habitat diversity. 
REACH 2

The middle reach covers the corridor area between river mile seven and 17 (Plate 3). Reach 2 has the lowest gradient (10.3 feet per mile), resulting in the largest floodplain area and greater meandering of the creek. Land use in this reach ranges from commercial to residential to rural residential, and agricultural.

Where residences abut the creek, homeowner landscaping encompasses different strategies. Some leave a natural buffer of vegetation between the yard and the creek. Others mow lawns to the water's edge, clipping all overhanging vegetation off stream banks, often discarding the yard debris into the creek. Channel maintenance efforts by residents for flood control purposes, include removal of overhanging trees and instream debris. On some properties, small dikes and revetments have been established along the creek in an attempt to stave off flood waters from yards.

Urbanization and residential development in the creek corridor ends abruptly after Johnson Creek meanders through Main City Park in Gresham (river mile 15.5), vegetation becomes dense and well developed. The riparian vegetation contributes woody debris which forms large debris jams in the creek. Here, the deepest natural pools have formed, interspersed by riffle-run sequences. The second of two undisturbed riparian areas of Johnson Creek is found in this 
reach, but there are also considerable amounts of garbage in the water. Cattle have access to the stream in a number of places but some landowners have fenced off access to the tream. The data from the three sections sampled in Reach 2 are presented in Table 6 .

TABLE VI

RESULTS OF SURVEY ON REACH 2

\begin{tabular}{|c|r|r|r|r|r|r|r|r|}
\hline Section & $\begin{array}{c}\text { Distance } \\
(\mathrm{mi})\end{array}$ & $\begin{array}{c}\text { OE } \\
(8)\end{array}$ & $\begin{array}{c}\text { OV } \\
(8)\end{array}$ & $\begin{array}{c}\text { UB } \\
(\mathrm{ft} / \mathrm{mi})\end{array}$ & $\begin{array}{c}\mathrm{R} \text { ( }) \text { S } \\
(\# / \mathrm{mi})\end{array}$ & $\begin{array}{c}\text { RW-I } \\
(\# / \mathrm{mi})\end{array}$ & $\begin{array}{c}\text { WD-S } \\
(\# / \mathrm{mi})\end{array}$ & $\begin{array}{c}\text { WD-I } \\
(\# / \mathrm{mi})\end{array}$ \\
\hline $2 \mathrm{~A}$ & 2.14 & 70.2 & 49.5 & 106.1 & 25.2 & 5.6 & 34.6 & 9.8 \\
\hline $2 B$ & 1.30 & 49.2 & 19.6 & 30.8 & 2.3 & 2.3 & 19.2 & 4.6 \\
\hline $2 \mathrm{C}$ & 2.00 & 90.2 & 29.2 & 155.0 & 27.0 & 12.0 & 50.0 & 22.0 \\
\hline Total & 5.45 & 209.6 & 98.3 & 291.8 & 54.5 & 19.9 & 103.8 & 36.4 \\
\hline Average & 1.82 & 69.9 & 32.8 & 97.3 & 18.2 & 6.6 & 34.6 & 12.1 \\
\hline
\end{tabular}

Section 2A

In section 2A riparian vegetation increases upstream as homes decrease in proximity to the stream. At river mile 7.1, Johnson Creek is only about eight to ten feet wide and is confined to a very deep, U-shaped, entrained channel. The sides are overhung by grasses, bushes, and shrubs, and the stream shaded by sparsely located trees. The dense, overhanging vegetation provides considerable cover. Some landowners have landscaped lawns up to the riparian strip, but most leave the streambank and crest alone.

The flat landscape is dominated by fields and a wide floodplain. The creek appears to have been dredged in some places and armored in others. There is hardly a perceptible 
flow in some of the slower stretches. At river mile 7.9 the creek flows along the base of a steep hill lying to the north, and widens to 25 feet. At river mile 8.5, Johnson Creek flows through Leach Botanical Gardens where there is no human encroachment on the creek for the first time since Johnson Creek Canyon. There are few houses and only two roads cross the creek in this stretch. There has recently been some land clearing with a small timber operation, and one farm allows cattle access to the stream. There is little bank armoring save for a of couple bends just below a covered bridge at river mile 9.2. Where the only residence abuts the creek (river mile 9.18) the owners have completely trimmed all vegetation from the bank and its crest and dumped it into the creek.

The floodplain has a heavy, early- to mid-successional forest growth. The banks are abundantly overhung with live vegetation, while considerable amounts of woody debris lie in the channel. There are some boulders in the stream providing habitat diversity. Due to the lack of meanders and the bank armoring, this reach has minor bank undercutting.

\section{Section 2B}

Section 2B starts just south of Powell Butte at river mile 10. In this section, Johnson Creek is almost completely armored until river mile 10.4, after which the floodplain widens. The creek traverses the landscape in 
long meanders. This is a residential/agricultural area with no commercial development.

Lawns are manicured to within a few feet or right up to the creek bank, limiting bank vegetation. Riparian cover is patchy with open stretches of creek decreasing its contribution of shade, woody debris, and root wads. With the entrenchment of the creek, livestock have difficulty accessing the stream. In some instances fences have been erected in the steepest places, probably to prevent injury to the livestock. Except for a few cases livestock have direct access to the creek, trampling the stream bank causing erosion and denudement.

The riparian vegetation is limited to overhead cover by streamside trees and bushes in well landscaped yards. The creek is up to 20 feet wide, with most woody debris and root wads removed, eliminating instream cover. In some of the dredged areas there is little perceptible flow, with the water appearing stagnant.

There is a high percentage of overhead enclosure until river mile 10.3, but gets patchy upstream, where property owners have thinned or removed creekside trees. Riparian vegetation and its contribution to stream habitat increases going upstream in this section. Most notably, bank undercutting occurs where there is no armoring.

The data reflect increased riparian manipulations along the corridor with changing land use, which affects riparian 
areas by decreasing vegetation's influence on stream habitat diversity.

Section 2C

Section 2C runs southeast for two miles from river mile 15 to 17, beginning in Gresham Main City Park where the creek has been reconstructed with meanders. Thick grasses overhang the twelve foot wide creek. Banks here are undercut, with trees planted along the creek for shade. As the creek leaves Gresham, residences diminish in number and sit further away from the creek. Landscaping of yards has removed woody debris, but low streambank vegetation is present. Most landowners have left larger trees and bushes, and bank vegetation. Riparian vegetation becomes increasingly dense with mid- to late- successional forest and is a mixture of conifers and deciduous trees. The floodplain widens and stream habitat becomes increasingly more complex as the channel fills with woody debris contributed from the forest, and as root wads armor the sides. With the lack of channelization, as in previous reaches, the stream adapts a more natural state. The banks are low and the floodplain has thick layer of deposited organic matter contributed by the forest. In two areas the channel has braided and established side channels filled with woody debris and root wads, forming still pools. Along with section IB, there appears to be more cover and habitat 
complexity in this stretch than other places along Johnson creek.

The Springwater Trail Corridor to the north of the creek shields the corridor from development pressures. However, on the south side, housing developments are being built. Hogan creek, at river mile 16.8, is being adversely affected by residential construction through land clearing with inferior sediment control efforts, resulting in a deposited alluvial fan at the mouth of Hogan Creek indicating stream disequilibrium transferred from Hogan to Johnson creek. The stream habitat continues to be diverse with little residential development along the stream's heavily forested floodplain.

\section{REACH 3}

The final reach extends from river mile 17 to the headwaters of Johnson Creek (Plate 3 ). The landscape is dominated by smooth rolling hills with a few steeper draws leading to the small intermittent surface drainages that feed this upper part of Johnson Creek. Land use in the upper basin is nursery agriculture, rural residential, and farmland. Runoff from land use combined with the steeper topography and the relatively nonpermeable nature of the soils of Reach 3 cause frequent flash floods. Heavy precipitation is followed by a sharply-peaked hydrograph, resulting in rapid conveyance of water downslope. 
Johnson Creek and its tributaries have been diverted to fill small farm ponds and the creek still flows around dikes or revetments holding the pond waters. There is viable riparian vegetation lining the creek on residential properties. On the more managed farms there are only small forbs and grasses along the creek. In the places where cattle or horses have direct access to the stream, the banks are degraded and erosion increased. Some of the pasture land has suitable riparian habitat where access to livestock is limited. Overhanging or undercut banks afford fish cover. Healthy pasture, with stable streambanks, exists where the riparian vegetation's root systems have stabilized the bank and created habitat complexes.

The creek has a naturally spaced riffle-run sequence. Even with the increased gradient, there are no long extensive riffles. Large deep pools are nearly absent, due to the lack of large organic debris. There is some smaller woody debris in the creek accompanied by garbage and old tires, which, ironically, supply habitat complexity. Results of the three sections are presented in Table 7 .

\section{Section 3A}

In section 3A the creek ranges in width from 15 to 30 feet, with a channel that braids and has formed large organic debris jams and pools. Instream habitat is natural and complex and corresponding riparian influences are diverse. Stream banks are composed of large amounts of 
finer sediment. The floodplain vegetation is wetland and mixed forest. There is no evidence of channel alterations.

\section{TABLE VII}

RESULTS OF SURVEY ON REACH III

\begin{tabular}{|c|r|r|r|r|r|r|r|r|}
\hline Section & $\begin{array}{c}\text { Distance } \\
(\mathrm{mi})\end{array}$ & $\begin{array}{c}\text { OE } \\
(8)\end{array}$ & $\begin{array}{c}\text { OV } \\
(8)\end{array}$ & $\begin{array}{c}\text { UB } \\
(\mathrm{ft} / \mathrm{mi})\end{array}$ & $\begin{array}{c}\text { RW-S } \\
(\# / \mathrm{mi})\end{array}$ & $\begin{array}{c}\text { RW-I } \\
(\# / \mathrm{mi})\end{array}$ & $\begin{array}{c}\text { WD-S } \\
(\# / \mathrm{mi})\end{array}$ & $\begin{array}{c}\text { WD-I } \\
(\# / \mathrm{mi})\end{array}$ \\
\hline $3 \mathrm{~A}$ & 1.17 & 99.1 & 29.5 & 162.4 & 25.6 & 12.8 & 54.7 & 29.1 \\
\hline $3 \mathrm{~B}$ & 1.03 & 67.1 & 39.0 & 339.8 & 16.5 & 3.9 & 49.5 & 8.7 \\
\hline $3 \mathrm{C}$ & 1.06 & 58.2 & 29.9 & 268.9 & 3.8 & 0.9 & 37.7 & 6.6 \\
\hline Total & 3.25 & 224.4 & 98.4 & 771.1 & 45.9 & 17.6 & 142.0 & 44.4 \\
\hline Average & 1.08 & 74.8 & 32.8 & 257.0 & 15.3 & 5.9 & 47.3 & 14.8 \\
\hline
\end{tabular}

with only ten houses along creek the riparian corridor is heavily forested and stream habitat is very heterogenous. There is fenced and unfenced grazing for a small herd of cattle which have access to the creek. Disturbance to the stream and the banks by cattle is minimal though, since there is no evidence of them crossing the creek or trampling the banks.

At river mile 18.7 small farms and homes surround the creek, and manipulation of the riparian corridor increases with corresponding declines in woody debris and root wads. Thick grasses and forbs create good overhanging stream bank vegetation when overhead enclosure declines. Section $3 \mathrm{~A}$ has viable riparian stream habitat, this condition changes going upstream into section $3 B$. 
Section 3B

Section 3B is characterized by the rolling hills and small valleys of the eastern portion of the basin. The creek is five to ten feet wide in this section as it winds through a fragmented riparian corridor. Iand use varies, with rural residences, small farms with livestock or horses, hay fields, and commercial nurseries. Some landowners leave stands of trees and brush while others limit the vegetation, mowing to the edge of the creek. Banks are stable with dense grasses or young, mixed successional forest. Undercut banks in the channel offer cover in the absence of larger riparian vegetation. Dumping of household garbage in the stream is evident where the section first starts.

Thin riparian vegetation has been left standing on the creek margins as it winds its way through the fields. Woody debris and root wads are lacking though the channel has brush and overhanging vegetation. The creek is unfenced, allowing livestock access. There is considerable bank degradation and erosion at livestock crossings on the farms. The floodplain is broader with intermittent wetlands alongside the creek. Where overhead enclosure is lacking and livestock access is limited, or grazing pressure is less, well vegetated, stable, undercut banks provide cover.

\section{Section 3C}

In section $3 C$ the creek is 4 to 8 feet wide. Land use is mainly nursery agricultural. Overhead enclosure is lower 
due to increased riparian zone disturbance. Stands of riparian trees are patchy and intermittent, varying in age and composition. Some are monospecific, with either firs or deciduous trees providing some woody debris and root wads.

The creek is bounded by nurseries until river mile 21.9. There is more diverse riparian vegetation in the first half of the reach but diminishes with increased nursery operations and farm land use. In this section there is more riparian vegetation where there are residences as opposed to farms and nurseries. Overhead riparian enclosure decreased with the farm fields and nurseries, though incidence of undercut banks increased. Fields often provide good cover to the stream with overhanging vegetation, where thick grasses and brush grow providing bank stability. Where there are residences with landscaped yards, overhead enclosure is higher but there is a decreased incidence of overhanging streamside vegetation.

In the upper rural residential areas the creek is covered with large dense stands of mixed deciduous and coniferous trees. Homes are set back in the trees with little attempt made to manage the creek. The habitat complexity increases with woody debris. The data reflect the higher degree of riparian manipulation associated with agricultural land use. 
SUMMARY OF RESULTS

The results are summarized in Table 8 and Figures 11 through 18 (pages 73 - 81). The following summary relates to these figures and table.

over 53 percent of suitable channel for salmonids was surveyed in nine sections along Johnson Creek. Reach 1 was the most urbanized and channelized reach of the Johnson Creek corridor and the data reflect the limited amounts of riparian-influenced salmonid habitat features. Overhead enclosure, overhanging vegetation, root wads and woody debris are the least abundant in this reach. Reach 2 had fewer undercut banks than Reach 1, this is due to the unchannelized, natural section running through Johnson Creek Canyon in Reach 1. The banks of the unarmored reaches are undercut by currents, the lithified alluvium has allowed undercutting to occur without bank destabilization. This is a geomorphic anomaly along the creek since banks composed of lithified alluvium occurs only here.

Reach 2 had the highest amount of large and small root wads. This reach has the second highest figures for large and small woody debris and overhead enclosure, with the least amount of undercut banks of all three reaches. overhanging vegetation in this reach is equal to that of Reach 3, and is due to the residential and small farm land use throughout reach, and gradient influences. With the lowest gradient of the three reaches, the sinuous channel is 
U-shaped, allowing overhanging vegetation greater influence. Residents generally leave the banks alone when the channel is deep, possibly as a safety feature or deterrent to approaching the creek too closely.

The considerable amount of riparian vegetation along the creek throughout this reach creates larger quantities of overhanging vegetation and overhead enclosure. The lack of disturbance and maintenance in the riparian zone accounts for the increased numbers of root wads and woody debris.

In Reach 3, the most rural and agricultural of the reaches, overhead enclosure, incidence of undercut banks, and amounts of woody debris were highest. This reach had the second highest number of root wads which may reflect the younger age of riparian trees in this reach. Weak flood waters this far up the basin tend to carry less organic debris downstream accounting for the greater incidence of woody debris.

The decreased incidence of both large and small root wads in Reach 3 may be a result of the former intensive timber harvests that have removed all older trees in the upper part of the basin. Root wads take considerable time to grow and develop. For the bank to undercut the root wad or streambank, bank stability is required. Otherwise the tree and root wad may become woody debris if the erosion proceeds beyond bank stability. 
The high occurrence of undercut banks may be due to the land use. The stream's erosive powers are less in this upper section so undercutting of banks is not so pronounced, but occurs with greater frequency in this reach due to higher incidence of grasses binding, and overhanging, the streambank.

The surveys on Johnson Creek showed diverse riparianinfluenced habitats in each of the three reaches. The data followed a distinct trend of increased viable riparianinfluenced salmonid habitat in all but 2 categories, root wads (in Reach 3) and undercut banks (in Reach 2). Generally, the greater the degree of channel and riparian alterations, the corresponding riparian-influenced habitat decreased in diversity and occurrence. 
TABLE VIII

SUMMARY OF RESULTS BY SAMPLE SECTION

\begin{tabular}{|c|c|c|c|c|c|c|c|c|c|}
\hline $\begin{array}{c}\text { Reach } \\
\text { section }\end{array}$ & $\begin{array}{c}\text { Digtance } \\
\text { (mi) }\end{array}$ & $\begin{array}{c}\text { Overhead } \\
\text { Enclowur } \\
(1)\end{array}$ & $\begin{array}{c}\text { Overhanging } \\
\text { vegetation } \\
(3)\end{array}$ & \begin{tabular}{|c|} 
Undercut \\
Banks \\
$(\mathrm{ft} / \mathrm{ml})$
\end{tabular} & $\begin{array}{c}\text { Small } \\
\text { Root Wads } \\
(t / m 1)\end{array}$ & $\begin{array}{c}\begin{array}{c}\text { Large } \\
\text { Root Wada } \\
(f / m i)\end{array} \\
\end{array}$ & $\mid \begin{array}{c}\text { Small Woody } \\
\text { Debrie } \\
(\mathrm{f} / \mathrm{ml})\end{array}$ & \begin{tabular}{|c|} 
Large Woody \\
Debrla \\
$(f / \mathrm{ml})$ \\
\end{tabular} & $\begin{array}{c}\text { Parameter } \\
\text { Average }\end{array}$ \\
\hline $1 \mathrm{~A}$ & 1.09 & 45.8 & 8.8 & 0.0 & 11.0 & 0.9 & 1.8 & 1.8 & 10.02 \\
\hline 2B & 1.15 & 88.3 & 47.1 & 330.4 & 19.1 & 9.6 & 60.0 & 25.2 & 82.82 \\
\hline $1 C$ & 1.00 & 53.4 & 27.9 & 50.0 & 15.0 & 1.0 & 12.0 & 3.0 & 23.19 \\
\hline $2 A$ & 2.14 & 70.2 & 49.5 & 106.1 & 25.2 & 5.6 & 34.6 & 9.8 & 43.01 \\
\hline 2B & 1.30 & 49.2 & 19.6 & 30.8 & 2.3 & 2.3 & 29.2 & 4.6 & 18.29 \\
\hline $2 C$ & 2.00 & 90.2 & 29.2 & 155.0 & 27.0 & 12.0 & 50.0 & 22.0 & 55.06 \\
\hline $3 A$ & 1.17 & 99.1 & 29.5 & 162.4 & 25,6 & 12.8 & 54.7 & 29.1 & 59.03 \\
\hline 3B & 1.03 & 67.1 & 39.0 & 339.8 & 26.5 & 3.9 & 49.5 & 8.7 & 74.93 \\
\hline $3 c$ & 1.06 & 58.2 & 29.9 & 268.9 & 3.8 & 0.9 & 37.7 & 6.6 & 58.00 \\
\hline Average & 1.33 & 69.05 & 31.16 & 160.37 & 16.18 & 5.45 & 35.51 & 12.32 & 47.15 \\
\hline
\end{tabular}

Parameter Average is a relative measure of overall habltat feature abundance. 
Percent Overhead Enclosure

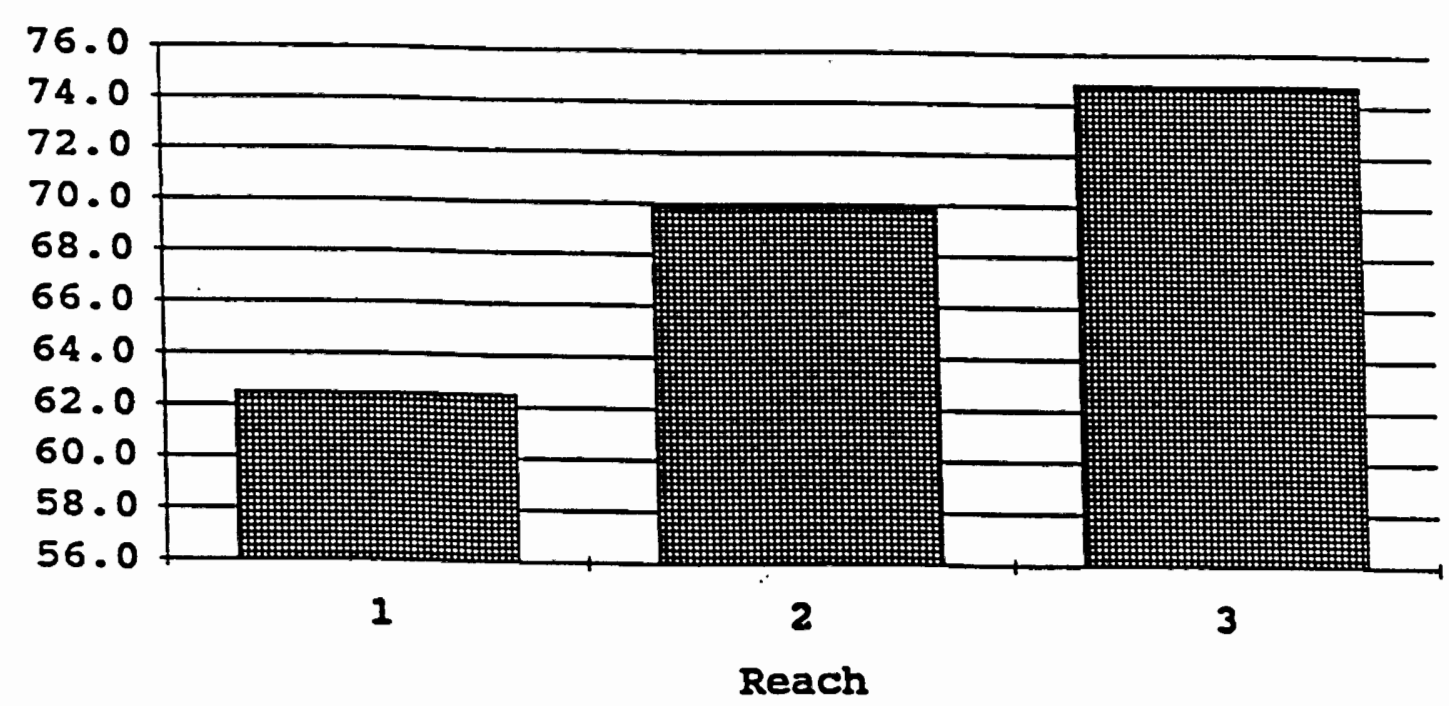

Figure 11. Average percent overhead enclosure per reach. 
Percent overhanging Vegetation

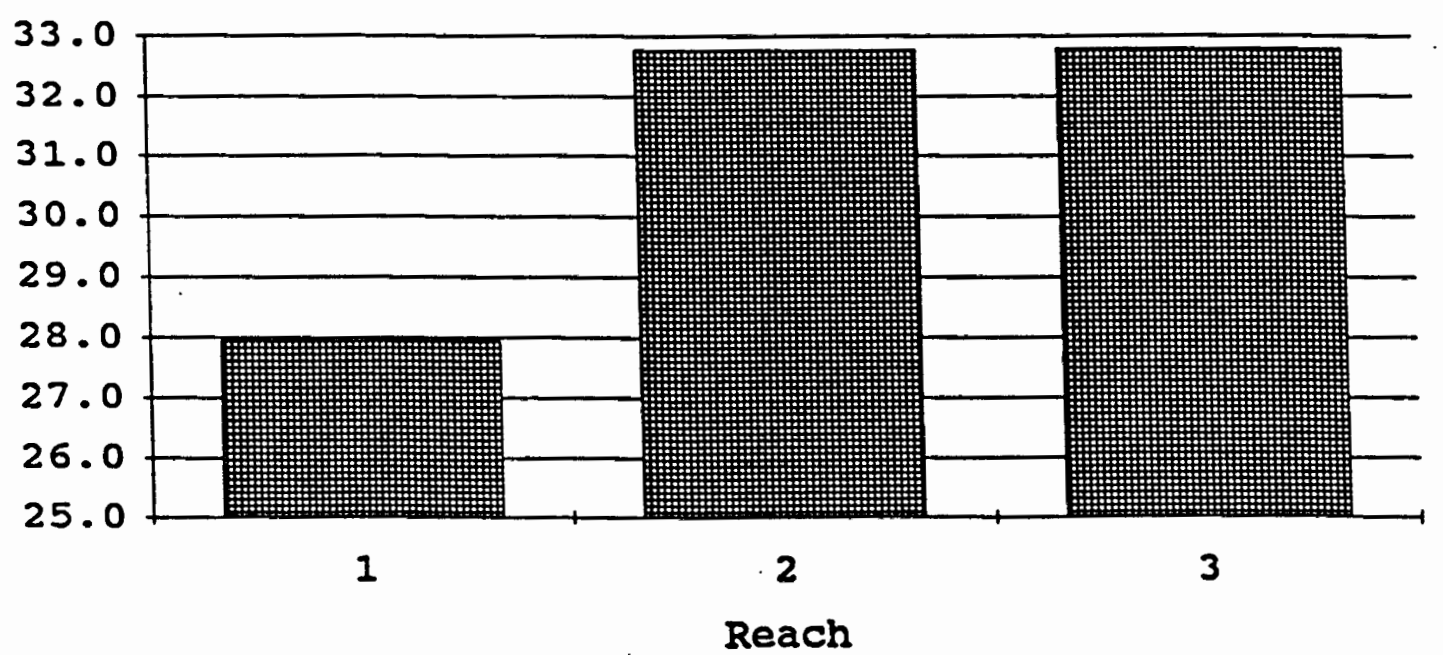

Figure 12. Average percent overhanging vegetation per reach. 
Undercut banks (feet/mile)

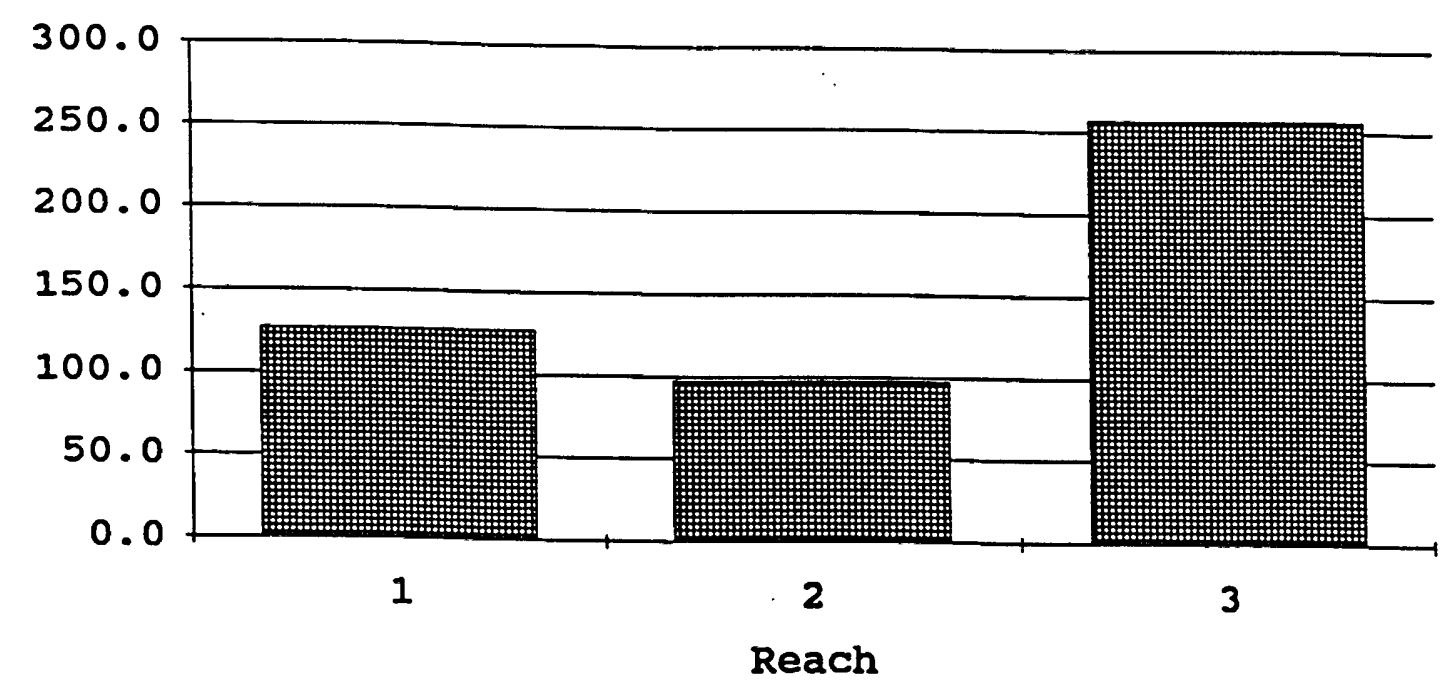

Figure 13. Average feet per mile of undercut banks per reach. 
Small Root Wads Per Mile

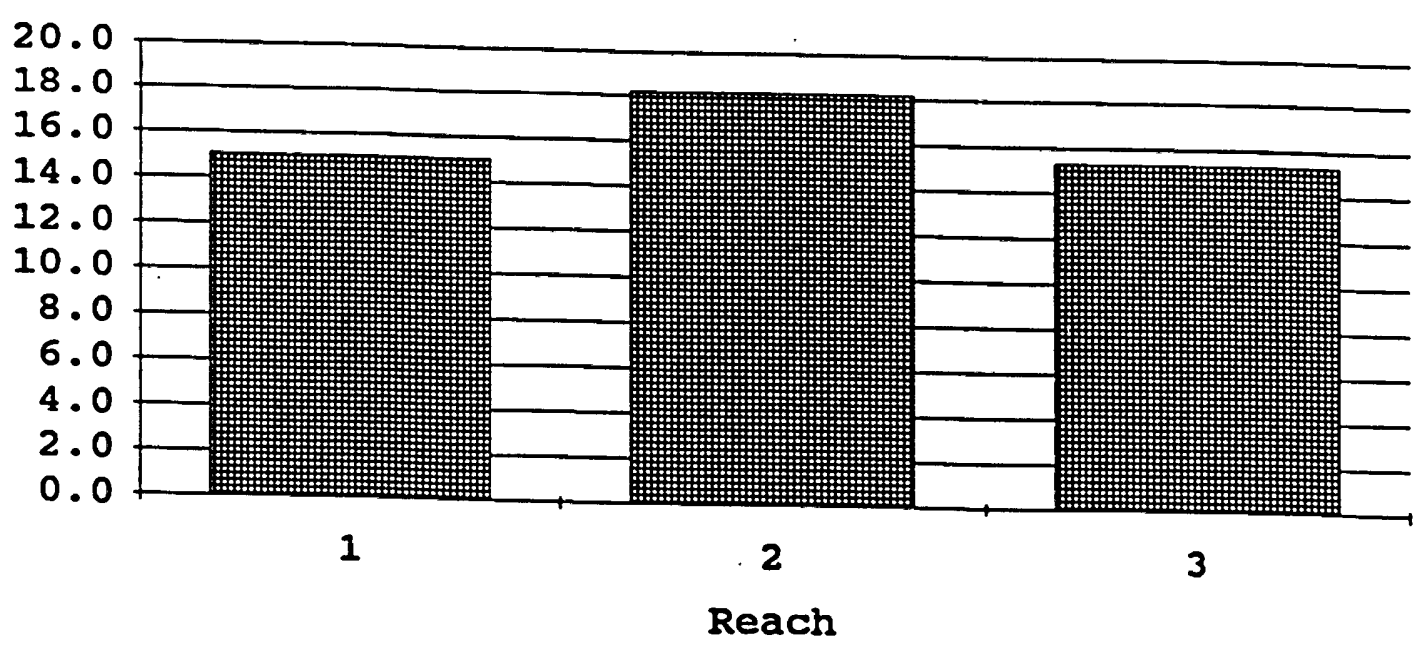

Figure 14. Average number of small root wads per mile. 
Large Root Wads Per Mile

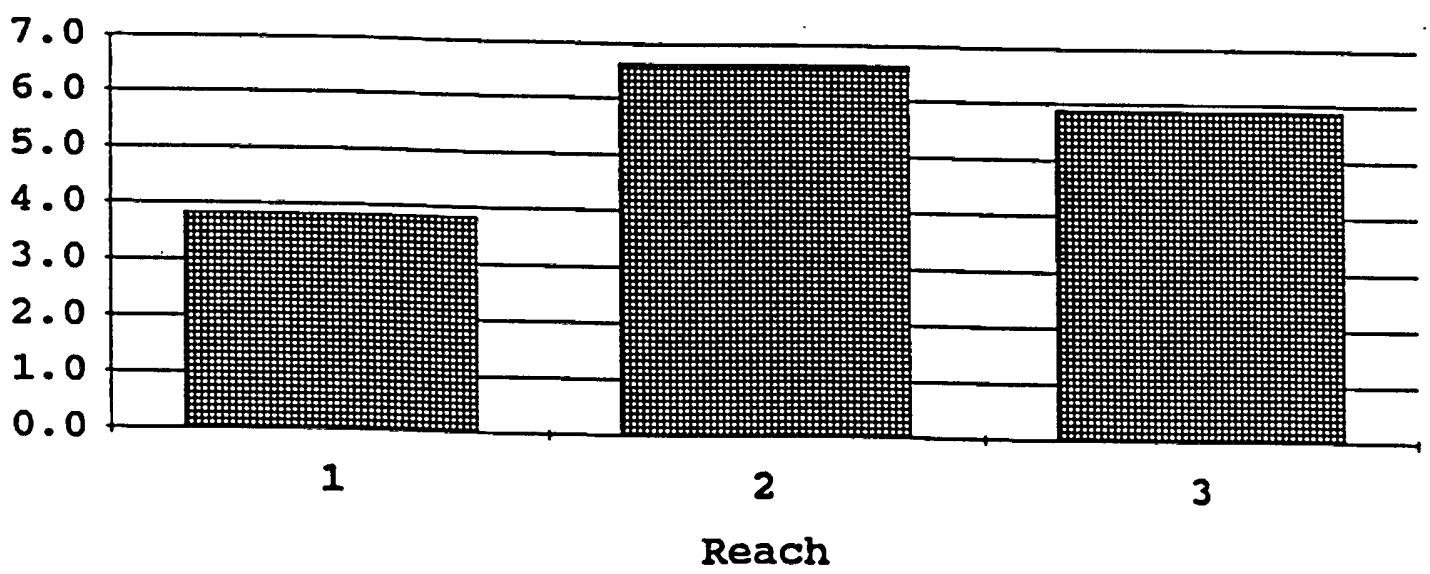

Figure 15. Average number of large root wads per mile. 
Small Woody Debris Per Mile

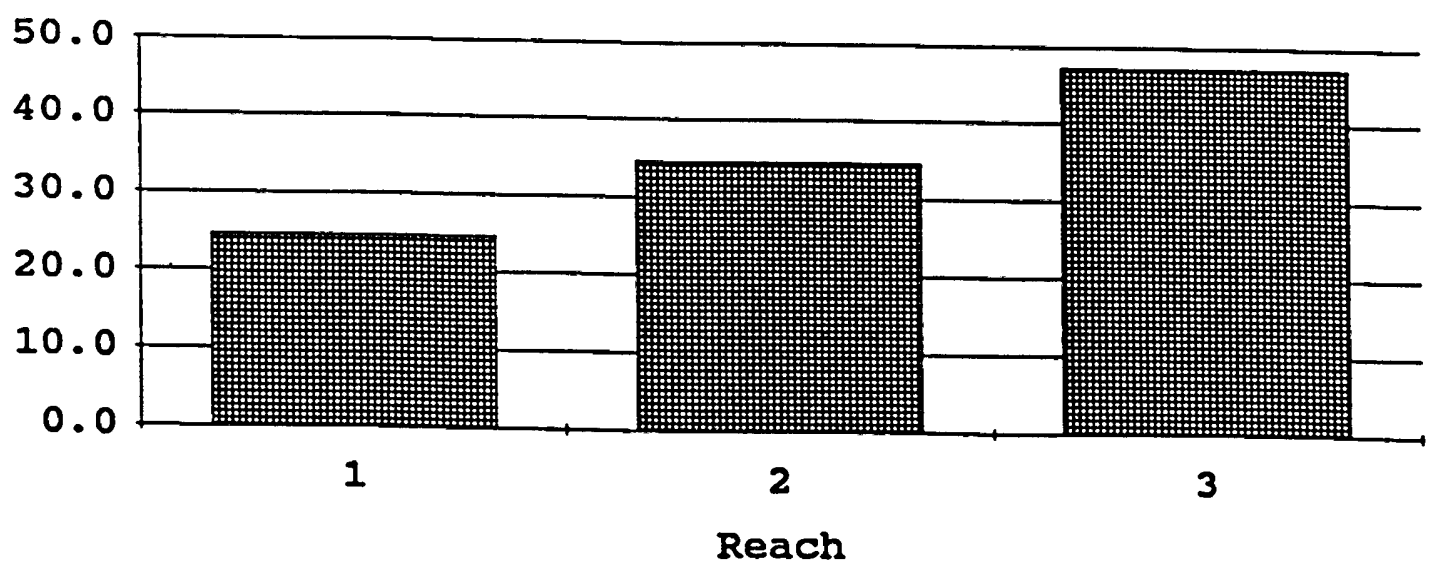

Figure 16. Average number of small woody debris per mile. 
Large Woody Debris Per Mile

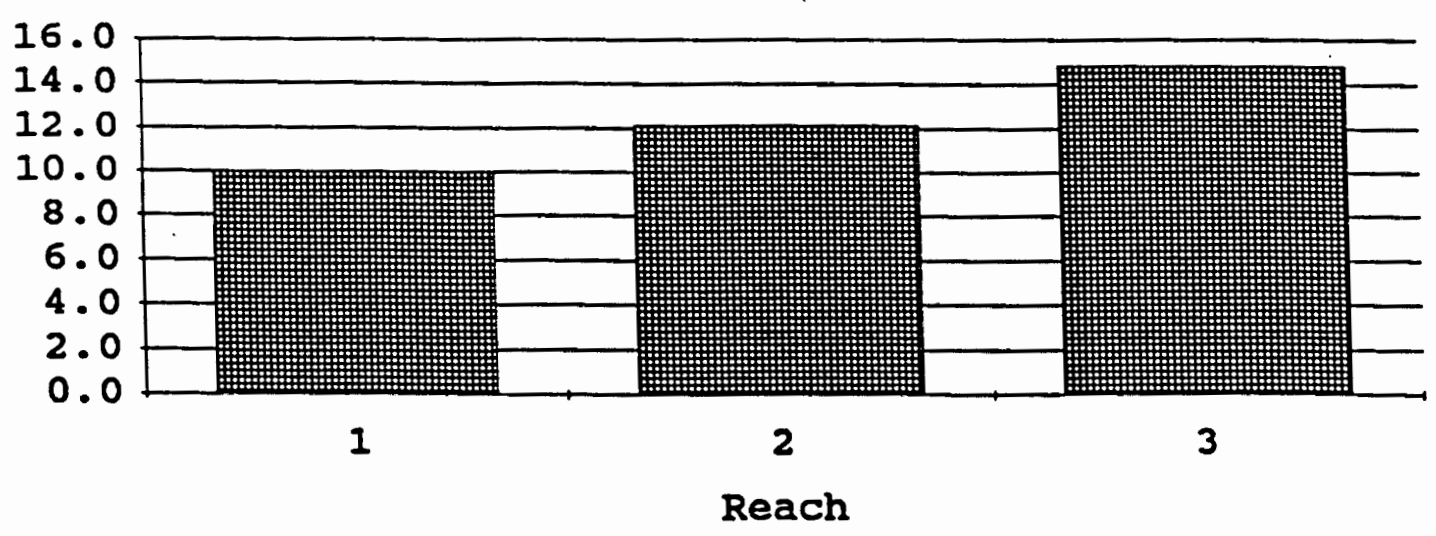

Figure 17. Average number of large woody debris per mile. 


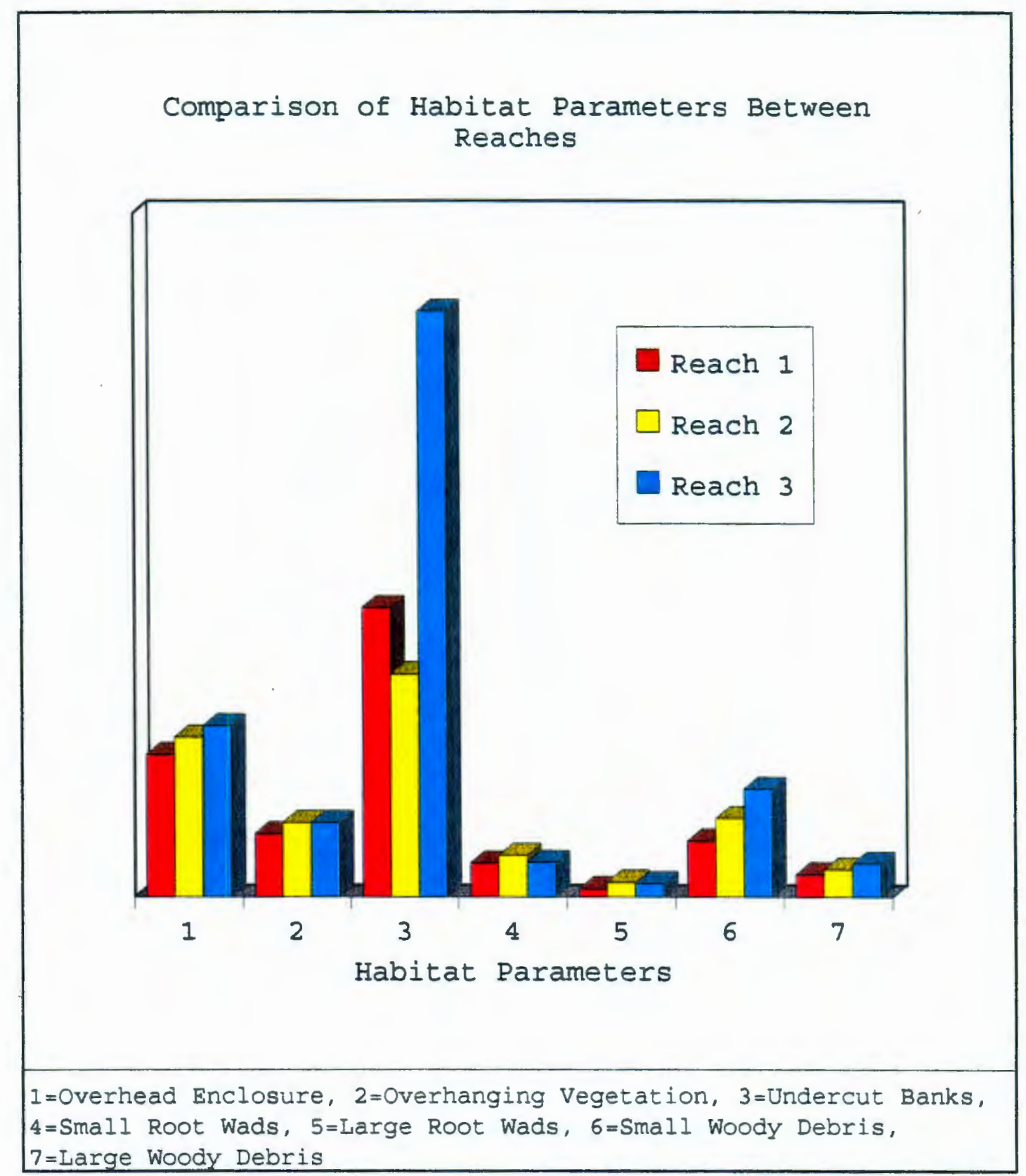


CHAPTER VI

\section{DISCUSSION}

This research tested the hypothesis that the physical features which make up riparian-influenced salmonid habitat are not abundant in Johnson Creek due to the effects of urbanization. The relative overall abundance of riparianinfluenced habitat features for anadromous salmonids offered by a healthy near-stream riparian zone throughout the Johnson Creek corridor was determined. It was found that riparian-influenced salmonid habitat has been considerably altered throughout the corridor due to urban, residential, and agricultural development, accompanied by flood control. The present riparian conditions are a result of a series of events including the construction of large mainstem dams on the columbia River, construction of flood control structures and increasing water quality problems due to urbanization and agricultural land use. The plight of the wild salmon recently entered public recognition as an important regional resource. Sound decisions to preserve this resource must be linked to present fish populations and existing habitat conditions throughout the corridor.

The natural areas in each reach (Johnson creek canyon and Tideman Johnson Park (Section 1B), Leach Botanical 
Gardens (2B) and downstream of Gresham (2C) and section $3 A$ ) showed considerably more positive riparian influences on instream habitat than other areas. Riparian-influenced instream habitat was greatest in these least disturbed areas of the stream, and in those without channelization. Downstream areas (river mile 6 to the mouth) where urbanization increases, the creek has the most homogenized instream habitat due to extensive channelization and armoring and urbanization in the riparian corridor. These physically-constrained creek reaches tend toward straight, single channels lacking in lateral heterogeneity and instream salmonid habitat. In contrast, unconstrained reaches are typically complex and diverse in habitat types, possessing braided channels and broad floodplains and greater standing salmonid densities (Gregory et al. 1991). These areas (Sections $2 \mathrm{C}$ and $3 \mathrm{~A}$ ) tend to offer greater habitat diversity and serve as refugia for salmonids during floods.

In Johnson Creek's pastureland areas, riparian vegetation was often minimal as in section $2 \mathrm{~B}$. With livestock grazing there is often little or no riparian vegetation, where cattle or horses have direct access to the creek. There was more riparian vegetation influencing the stream in unchannelized rural residential areas than in unfenced pastureland. This is probably because riparian vegetation is an aesthetically pleasing aspect to 
landowners. There was more riparian vegetation in nursery agricultural areas than in pastureland. Nursery operations seem to ignore small trees, bushes, and grass in the riparian zone, but take out the larger trees to increase sunlight to the crops. Healthy riparian vegetation can serve as a nutrient filter in these agricultural areas (Lowrance et al. 1984).

Nursery agriculture dominates land use east of river mile 18.4. Often the furrows run downslope, allowing conveyance of sediment to the creek. The farmed landscape is often that of high disturbance with seasonal harvest cycles reducing the land to bare dirt ready for planting. The nursery farm industry relies heavily on chemical pesticide and fertilizer applications. In addition, pesticide use, to reduce unwanted vegetative growth in the ditches and fields, is prevalent. The chemicals make their way into the stream, often through drainage ditches that are at most grass or dirt. As the stream flows through nursery fields, grasses are often the only riparian vegetation present offering overhanging vegetation as habitat.

There is a lack spawning gravel of suitable size and quality above river mile 18.4. This may be due to the natural inverted nature of the basin and the high sediment inputs due to erosion from the land use practices and erodible soils. Sediment fills in the interstitial spaces in the gravelly riffles, rendering them unsuitable as 
habitat for fish eggs, hatchlings, or macroinvertebrates. Spawning fish may find suitable spawning gravel, but eggs and hatchlings will encounter potentially lethal interstitial sediments and toxic substances over the incubation term. Sediment removal and floodplain retention of sediment during higher flows is almost nonexistent on Johnson creek due to the effects of channelization and flood control. Sediment control is a major concern in management of the creek. The watershed above river mile 19 has potential for juvenile rearing habitat, but unless agricultural pressures, agrochemical and sediment inputs are curbed there is little hope for salmon survival.

Comparing overall habitat feature abundance (Figure 19) between sections, section 1B stands out as having the highest parameter average. Section $1 B$ is in Johnson Creek Canyon lying in the most urbanized reach of the creek. Section IA has the lowest parameter average of the nine samples, it lies less than one river mile from section 1B. 
Relative Overall Habitat Feature Abundance

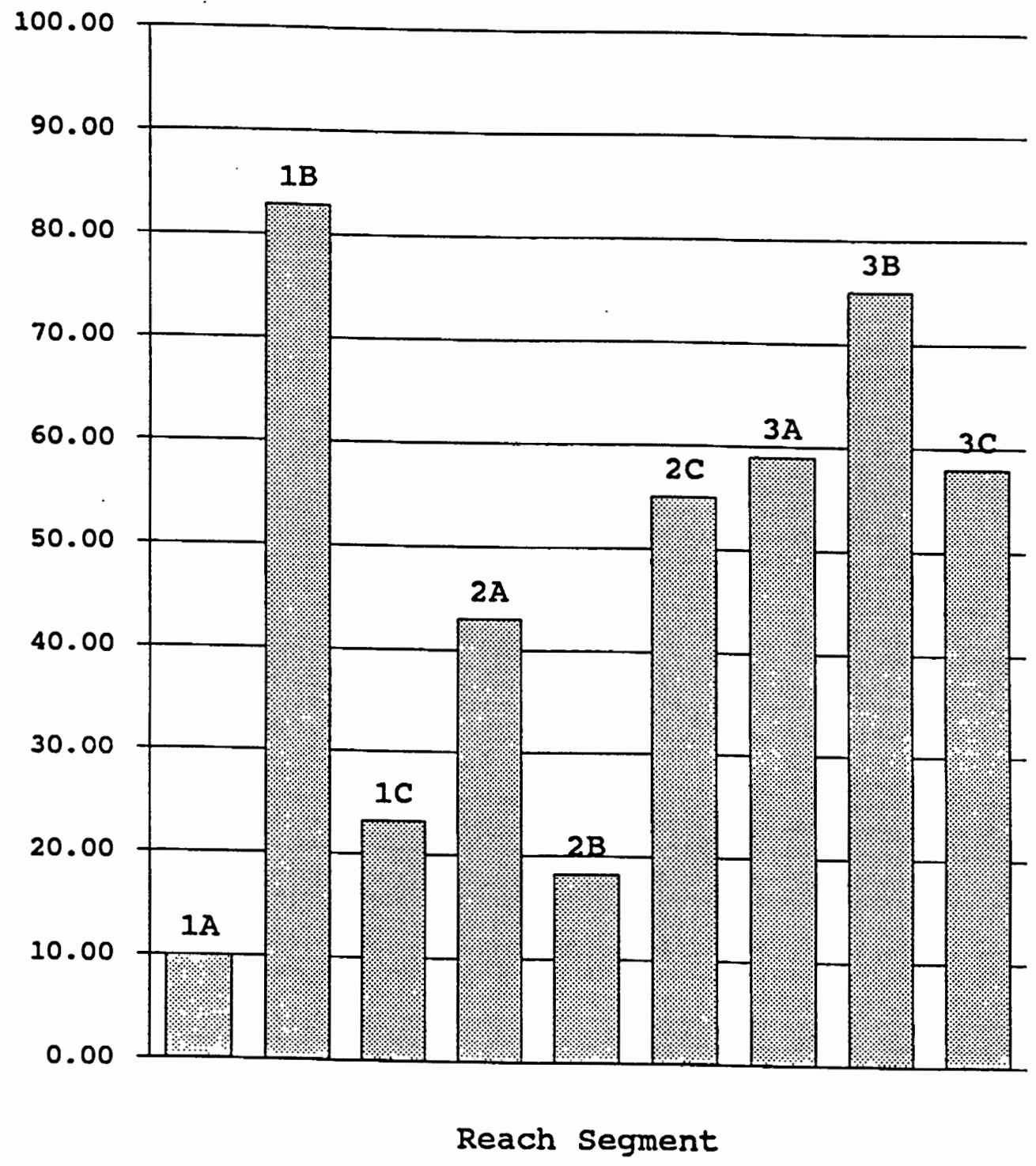

Figure 19. Relative overall habitat feature abundance. 
Section 1A's riparian-influenced salmonid habitat features are most heavily impacted by urbanization while 1B's are the least impacted. Little development can occur in Johnson Creek Canyon due to the topography and land use zoning. Both Section $2 B$ (rural residential with small farms and livestock) and section 1c (residential with light industry and commercial development) had less than 30.00 as a relative measure of overall habitat feature abundance. Reach 3 had the next three highest parameter averages indicating that in the upper agricultural portion of the watershed there is still an abundance of riparian-influenced salmonid habitat features. The results, based solely on the habitat features and not relative stream size, indicate that Reach 3 had the most riparian-influenced salmonid habitat features. This would indicate that urbanization of the lower two reaches ( 1 and 2 ) has reduced riparian-influenced salmonid habitat features.

The results showed woody debris to be lacking in the channelized urban and residentially landscaped sections along Johnson Creek. Density of woody debris tends to be highest in first- and second-order streams since woodcontributing area to stream area ratio is the highest and because stream power is lowest (Harmon et al. 1986; Keller and Swanson 1979). As a landscape feature, Johnson Creek's active channel grows in size as it moves through the basin, whereas the riparian vegetation does not. 
As stream size decreases the influence a particular piece of woody debris, a root wad, overhead shading or overhanging vegetation has on stream habitat, proportionally increases. Conversely, the wider the stream, the less influence a tree, shrub, root wad, or woody debris has on the stream. In the upper reaches, smaller trees will still sufficiently shade the stream, but in the lower reaches, the wider stream will require more mature and larger trees for the same proportional amount of shade. This explains why Reach 3, the upper reach of Johnson Creek, showed the highest amount of woody debris (47.3 small and 14.8 large pieces per mile) and the second highest number of root wads (15.3 small and 5.9 large ones per mile). Johnson Creek's active channel here, is smallest in size and less influenced by flood waters moving woody debris downstream. Section 1A is especially lacking with only 1.8 large and small pieces of woody debris. This is due to the extreme amount of channelization in the lowest part of Johnson Creek. Johnson Creek lacks sufficient numbers of aquatic insects due to poor water quality, so salmonids in the creek may rely more on terrestrial insects as primary food source. With the lack of riparian vegetation along sections of Johnson Creek, terrestrial insect input into the stream may be limited, reducing food supply to salmon.

Human impact on Johnson Creek is exercised through land use practices, channelization, and riparian management. One 
consequence is stream temperature modification. The data reveal a lack of stream shading allowing direct sunlight on large portions of the creek contributing to increased water temperatures. Overhead enclosure is less than 60 percent in 4 Sections: 1A, 45.8 percent; 1C, 53.4 percent; 2B, 49.2 percent; and 3C, 58.2 percent. An additional factor in temperature increases in Johnson Creek is the reduction of cool groundwater influxes due to groundwater withdrawal (City of Portland 1992C).

However, lack of overhead enclosure is not necessarily bad for fisheries. Past research has shown that unshaded stream reaches should support greater standing stocks of salmonids in West coast streams (Hawkins et al. 1983). With the considerable amount of open stream on Johnson Creek there exists the chance for a greater salmonid and macroinvertebrate populations in Johnson Creek. This is because higher light intensity increases primary production of algae, augmenting secondary production of benthic invertebrates, boosting the food supply available to fish (Chamberlin 1982), and extending the growing season and increasing fish growth rate (Holtby 1988). It was reported in 1975 that even with the existing water quality, a fair population of aquatic organisms existed indicative of fair to good water quality (Oregon Department of Environmental Quality 1975). During this survey and others the frequency, species diversity, and number of invertebrates in the creek 
was deemed to be severely depauperate (Carlson 1993; City of Portland 1992c; Ellis 1992). If other West Coast streams experienced greater productivity with increases in available light (Hawkins et al. 1983), Johnson Creek should also show this trend. Presently there are low populations of salmonids and aquatic insects in the creek. This points to other variables causing problems for the salmon in Johnson Creek.

Observations along the length of the creek revealed low abundance and diversity, with inconsistent densities of aquatic macroinvertebrates. Some reaches are devoid of any Iife attached to the substrate, whereas other stretches have some invertebrates and algae. These populations, where they exist, are low in species diversity and abundance. The biotic substrate composition changes abruptly in a number of areas indicating pollution by sediments, agricultural and industrial chemicals, possible conveyance of hazardous substances by groundwater, and incidental spills can all be suspect (City of Portland 1992c).

Johnson Creek, typical of many urban streams today, has a seven decade history of management and conflict, mainly concerning flooding and water quality. One hindrance to effective management is a perceptual disparity of the resource between riparian (and floodplain) residents and those geographically removed from the stream (Seltzer 1983). Cognizance of the resource by creekside residents is 
important because of their proximity to the riparian zone and stream. Only the riparian landowners can directly affect riparian vegetation and stream habitat. Few riparian landowners have actively managed the riparian zone in the stream corridor with salmonids in mind. Some residents mow their lawns to the water's edge, trimming all overhanging vegetation and removing woody debris, whereas others leave everything to natural forces with little or no streambank landscaping. Johnson Creek has overhanging and bank stabilizing vegetation where there is no streambank livestock grazing, or bank armoring, or a high degree of yard landscaping by residents.

Observations along the creek indicated that a U-shaped channel as in section $2 \mathrm{~A}$, is less likely to have the banks trimmed than a V-shaped channel. The V-shaped channel is prevalent downstream of river mile 15 to the mouth of Johnson Creek. This may have to do with the risk an individual takes approaching a U-shaped channel due to the relative instability of the banks. Maintenance of the bank crest, in this case, may therefore be perceived as a hazard by landowners, but the natural bank area provides needed riparian-influenced salmonid habitat features.

Johnson Creek has significant sediment problems. In Reach 1 and 2, where Johnson Creek has been channelized, diked, and urbanized, flood waters can no longer deposit sediment on the natural floodplain, but instead builds up in 
the creek channel. The dysfunctionality of Johnson Creek's floodplain contributes to sediment problems in the creek. Retention of sediment in the floodplain can occur in sections $2 \mathrm{~B}, 2 \mathrm{C}$, and $3 \mathrm{~A}$.

Hogan Creek, mentioned earlier, is a small tributary parallelling the west side of Hogan Road, river mile 16.8. It has been dammed to create a "lake", and the steep hills surrounding it stripped bare in preparation for housing development. The developer placed a few hay bales with plastic across the stream to prevent sediment from flowing downstream. A couple of days and one rainy spell later, the sediment barriers had been easily breached with considerable amounts of sediment flowing down the small tributary to Johnson Creek. Observations indicated that the gravel's interstitial spaces had been inundated by the fine sediments, and the resident cutthroat trout population put under stress (City of Portland 1992a). Hogan Creek is only one example in a series of developmental events of urbanization that occur throughout the basin, combining to form cumulative impacts of greater magnitudes of harm to the aquatic environment.

The establishment of healthy bank and channel vegetation is the best control of dynamic equilibrium in streams (Heede 1986). Improved streamside management by using vegetation and natural recovery processes in stream management rather than structural modifications has 
increased benefits with lower costs for restoration (Elmore and Beschta 1989). If streambank construction is required, long-term damage to a stream upon riparian vegetation removal can be negligible if bank vegetation is restored (Peterson 1989). However, stewardship of riparian vegetation is believed to be better than structural modifications (Elmore and Beschta 1989). 
CHAPTER VII

CONCLUSIONS

Riparian-influenced salmonid habitat features in Johnson Creek have been reduced due to the effects of urbanization. Insufficient salmonid habitat as influenced by decreased riparian vegetation as a result of urbanization, is a limiting factor to salmonid populations in Johnson Creek. However, other factors, such as water quality, sedimentation, thermal factors, and lack of macroinvertebrate food supplies, contribute to, and repress wild salmon populations.

This stream survey showed that many types of riparianinfluenced habitat are present along Johnson Creek, but they are spatially intermittent. Total habitat figures on Johnson Creek were obtained by extrapolating the results of the stream survey sections to the entire length of Johnson Creek's suitable habitat $(22.6$ miles). The extrapolated results are presented in Table 9. These figures are a relative measure and should only be used as a rough comparison to other urban streams in the region. No riparian-influenced salmonid habitat feature data on other streams was found. 
TABLE IX

EXTRAPOLATED VALUES FOR QUANTITIES OF RIPARIAN-INFLUENCED SALMONID HABITAT FEATURES ALONG JOHNSON CREEK

\begin{tabular}{|c|c|}
\hline Habitat Feature & Total \\
\hline \hline Overhead Enclosure & $69.05 \%$ or 15.6 miles \\
\hline Overhanging Vegetation & 31.168 or 7.04 miles \\
\hline Undercut Banks & 3624 feet \\
\hline Root Wads - Small & 365 occurrences \\
\hline Root Wads - Large & 122 occurrences \\
\hline Woody Debris - Small & 802 pieces \\
\hline Woody Debris - Large & 278 pieces \\
\hline
\end{tabular}

Suitable riparian habitat for the few wild fish returning is limited to locations where there is minimal riparian disturbance, a lack of property maintenance, and no channelization or bank armoring. This habitat is available to spawning salmon, provided the adult salmon make it upstream to these areas and are not removed or affected by poor water quality. The $0.8 \mathrm{mile}$ of stream channel between Johnson Creek Canyon and Tideman Johnson Park, and the 1.5 miles upstream of Leach Botanical Gardens, had areas of excellent habitat diversity. The best habitat for all fish life stages lies in the 3.3 mile stretch from river mile 15.3 to river mile 18.6, more than 15 miles upstream from the willamette River (Plate 4). The spatial arrangement of 
locations of riparian-influenced salmonid habitat matter (Foreman 1994). In the case of Johnson Creek, the distance a fish travels to spawn is critical since the farther upstream the fish goes the more vulnerable it is due to the extent of the urbanized area it has to traverse. However, once the salmon make it up this far they will find diverse habitat. Large stretches of stream without cover exist through which returning spawners must pass, and few, if any juvenile salmonids occupy these stretches.

Riparian landowners can employ management techniques to increase the fisheries resource. However, even if all riparian landowners managed their properties with best management practices for salmonid habitat, fish populations would still suffer from the other detrimental influences. Abuse of one environmental component of the creek will affect others needed to sustain wild salmon populations. On Johnson Creek the existing adequate riparian-influenced salmonid habitat needs to be supplemented by improving areas where there is little or no riparian vegetation influencing stream habitat.

Food supply and availability may be more important for salmonid production than habitat structure (Chapman 1966; wilzbach et al. 1986); this may be especially so in the case of Pacific Northwest salmonids (Gregory 1993). With the lack of macroinvertebrate food supplies in the creek, salmonids in Johnson Creek may depend more on riparian 
inputs of insects. Allowing diverse riparian vegetation to develop would increase allochthanous insect input to the creek.

Water quality is a serious problem in Johnson Creek. According to the U.S. Geological Survey (1990), Johnson Creek comprises about 0.5 percent of the total willamette River drainage area, but delivers contaminant loads equivalent to 10-15\% of the willamette River load totals (U.S. Geological Survey 1990). Given the adequacy of riparian-influenced salmonid habitat in undisturbed sections, and the low salmonid populations found in the creek, water quality may be the limiting factor to the fish and invertebrate populations in Johnson Creek.

Options exist to preserve and enhance riparianinfluenced salmonid habitat throughout Johnson Creek. There are an estimated 5.6 miles $(22.6 \%$ of the total length of the stream corridor, 24.88 of the suitable channel habitat) of designated parks or existing natural areas along the stream where impacts on riparian vegetation from existing development are limited. If present riparian conditions do not change due to development, there will be increased riparian influence and contributions to the stream environment along the Springwater Trail Corridor and Johnson creek Canyon, as the vegetation ages and undergoes succession, providing greater influence on stream habitat diversity. The effect of the Springwater Trail corridor as 
a geographic shield against major developmental encroachment, along the 13 miles it parallels Johnson Creek closely, is be an important factor in increasing salmonid populations (Plate 4 ).

Sediment inputs to the creek can be decreased by maintenance of healthy riparian strips in the agricultural sections of Johnson Creek (City of Portland 1992C), moderating the present dynamic disequilibrium. Areas of public landownership, such as the stretch oregon Department of Transportation owns along the creek in Reach 1, should not be mowed but rather planted with trees to provide shade to the creek. Grasses and bushes should be allowed to grow on the stream side where trees are inconvenient. With proper management, riparian-influenced stream habitat features can be enhanced to provide for salmonids along many stretches of Johnson Creek. Other critical problems do need addressing before riparian-influenced habitat features come into play. The current low numbers of salmonids do not use what habitat is available. To increase the presence of wild anadromous salmon in Johnson Creek, water quality must be improved and sediment erosion into the creek reduced to increase food supplies and protect critical habitats. Summer base flows must be restored to provide greater wetted area and more habitat, and to reduce stream temperatures and related thermal stress in fish. Hatchery fish introduction must be eliminated to decrease competition 
for food and space with wild fish, and to prevent negative genetic or disease vectors. Point and nonpoint pollution must be lessened, bringing water quality up to par with what salmonid fish and their macroinvertebrate diets require. Sport fishing should be terminated to decrease the already substantial pressures facing wild fish. This would allow salmon unhindered passage and greater access to available habitat. When these limiting factors are removed, the native anadromous fish of Johnson Creek will be able to take full advantage of the protective riparian-influenced salmonid habitat still available in the creek. 


\section{REFERENCES}

Abel, D.L. [ed.] . 1989. Proceedings of the California Riparian Systems Conference. General Technical Report PSW-110. U.S. Department of Agriculture Forest Service, Pacific Southwest Forest and Range Experimentation Station, Berkeley, California.

Adopt-A-stream Foundation. 1992. Streamlines 5:2-8. Everett, washington.

Anderson, N.H. and Sedell, J.R. 1979. Detritus processing by macroinvertebrates in stream ecosystems. Annual Review of Entomology $24: 351-377$.

Arthington, A.H.; Milton, D.A.: and McKay, R.J. 1983. Effects of urban development and habitat alterations on the distribution and abundance of native and exotic freshwater $f i s h$ in the Brisbane region, Queensland. Australian Joumal of Ecology $8: 87-101$.

Audubon Society of Portland. Undated. Urban Streams Series: Johnson Creek. Metropolitan Wildlife Refuge system Project, Portland, Oregon.

Audubon Society of Portland. 1990. Friends and Advocates of Urban Natural Areas (FAUNA). Oregon Community Foundation, Portland, Oregon.

Beckham, S.D. : Minor, R.: Toepel, K.A.; and Reese, J. 1988 . Prehistory and History of the Columbia River Gorge National Scenic Area, Oregon and Washington. Heritage Research Associates: Report 75. Eugene, Oregon.

Beschta, R., and Platts, W. 1986. Morphological features of small streams: significance and function. Water Resources Bulletin 22:369-379.

Bilby, R.E. 1984. Removal of organic debris may affect stream channel stability. Joumal of Forestry 82:609-613.

Bilby, R.E., and Bisson, P.A. 1987. Emigration and production of hatchery coho salmon (Onchorhynchus kisutch) stocked in streams draining an old growth and clearcut 
watershed. Canadian Journal of Fisheries and Aquatic Sciences 44 :13971407.

Bilby, R.E., and Likens, G. 1980. Importance of organic debris jams in the structure and function of stream ecosystems. Ecology 61:1107-1113.

Binns, N.A. and Eiserman, F.M. 1979. Quantification of fluvial trout habitat. Transactions American Fisheries Society 108:215228.

Bisson, P.A.; Bilby, R.E.; and Bryant, M.D. 1987. Large woody debris in forested streams in the Pacific Northwest: past, present, and future. In, Streamside Management: Forestry and Fisheries Interactions 57:143-190. University of Washington, seattle, Washington.

Boussu, M.F. 1954. Relationship between trout populations and cover on a small stream. Journal of Wildlife Management $18: 227-239$.

Bowlby, J.N. and Roff, J.C. 1986. Trout biomass and habitat relationships in southern ontario streams. Transactions American Fisheries Society 115:503-514.

Brown, G.W. 1969. Predicting temperatures of small streams. Water Resources Research 5:68-75.

Brown, G.W., and Krygier, J.T. 1970. Effects of clearcutting on stream temperature. Water Resources Research $6: 1133-1139$.

Bryant, M.D. 1983. The role and management of woody debris in west coast salmonid nursery streams. North American Journal of Fisheries Management 3:322-330.

Butler, R.I. and Hawthorne, V.M.. 1968. The reactions of dominant trout to changes in overhead artificial cover. Transactions American Fisheries Society $97(1): 37-41$.

Carlson, K.L. 1993. Hydrologist/fisheries biologist; personal communication, July 1993. Portland, Oregon.

Chamberlin, T.W. 1982. Influence of forest and rangeland management on anadromous fish habitat in western North America. General Technical Report PNW-136. U.S. Department of Agriculture, Forest Service, Pacific Northwest Research station, Portland, Oregon. 
Chapman, D.W. 1966. Food and space as regulators of salmonid populations in streams. American Naturalist 100:345357 .

Chapman, D.W. 1962. Effects of logging upon fish resources of the west coast. Journal of Forestry $60(8): 533-537$.

City of Gresham. 1991a. Environmental Assessment Report for Springwater Trail Corridor. By Harza Engineering for Parks and Recreation Division, Gresham, Oregon.

City of Gresham. 1991b. Environmental Report for the Springwater Trail Corridor Equestrian Trail. By Ester Lev for Parks and Recreation Division, Gresham, Oregon.

City of Gresham. 1988. Inventory of Significant Natural Resources and Open Spaces. Community and Economic Development Department, Gresham, Oregon.

City of Gresham. 1985. City of Gresham, Park and Recreation Plan. By Draggoo and Associates for Parks and Recreation Division. Gresham, Oregon.

City of Gresham. 1982. Drainage Management Study and Financial Program. By Kramer, Chin, and Mayo for Department of Planning, Gresham, Oregon.

City of Portland. 1992a. Compiled Reports:

Spring Spawning Surveys of 7 May - 4 June 1992;

Fall Spawning Surveys of 17 and 28 September 1992;

Fish Community Analysis of June 1992;

Fish Community Analysis of August 1992;

Temperature Monitoring of 4 June, 14 July, and 1 October 1992. By Beak Consultants for Bureau of Environmental Services, Portland, Oregon.

City of Portland. 1992b. Johnson Creek Corridor Committee: Johnson Creek Vision. By Woodward-Clyde Consultants for Bureau of Environmental Services, Portland, oregon.

City of Portland. 1992C. Johnson Creek Resources Management Plan. By Woodward-Clyde Consultants for Bureau of Environmental Services, Portland, Oregon.

City of Portland. 1992d. Johnson Creek Resources Management Program zoning map. By Woodward-Clyde Consultants and VESTRA Resources, Inc. for Bureau of Environmental Services, Portland, Oregon. 
City of Portland. 1992e. Johnson Creek Resources Management Program recreation map. By Woodward-Clyde Consultants and VESTRA Resources, Inc. for Bureau of Environmental Services, Portland, Oregon.

City of Portland. 1991a. Best Management Practices, a Draft Guide to Site Planning and Development for the Johnson Creek Basin. By Fishman Environmental Services for Bureau of Environmental Services, Portland, oregon.

City of Portland. 1991b. Physical Stream Survey Data Forms. By CH2M Hill for Bureau of Environmental Services, Portland, Oregon.

City of Portland. 1990a. Johnson Creek Corridor Planning District. Bureau of Environmental Services, Portland, Oregon.

City of Portland. 1990b. Clean Rivers Program. Bureau of Environmental Services, Portland Oregon.

City of Portland. 1990c. Johnson Creek Fishery Resources. By Fishman Environmental Services for Bureau of Environmental Services, Portland, Oregon.

City of Portland. 1987a. Public Facilities Plan, Combined Sewer Element. Bureau of Environmental Services, Portland, Oregon.

City of Portland. 1987b. Public Facilities Plan, Drainage Element. Bureau of Environmental Services, Portland, Oregon.

City of Portland. 1985. Lents Area Sump Suitability Study. By Century West Engineering Corporation for Bureau of Environmental Services, Portland, Oregon.

City of Portland. 1984. Sewerage Systems Facility Plan for the I-205 Corridor and the Johnson Creek Basin. Bureau of Environmental Services, Portland Oregon.

City of Portland. 1979. Sewer Needs for Lents and Foster-Powellhurst Neighborhood Areas. By Brown and Caldwell for Bureau of Environmental Services, Portland, Oregon.

City of Portland. 1935. Physical Stream Survey Data Forms. Bureau of Planning, Portland, Oregon.

Clackamas County. 1992a. Draft Neighborhood Parks Plans. Parks and Recreation District, Oregon City, Oregon. 
Clackamas County. 1992b. Surface Water Management Program Information. Department of Utilities, Oregon City, Oregon.

Clackamas County. 1989. Final Report: Sanitary Sewer Study, Johnson Creek Area of Clackamas County. Department of Utilities, Oregon City, Oregon.

Clackamas County. 1988. Draft: Clackamas County Public Facilities Plan, North Clackamas Urban Area, Storm Drainage Element. Department of Transportation and Development, oregon City, Oregon.

Clement, W.V. 1984. Effects of Urbanization on the Hydrologic Regime of Johnson Creek, Portland, Oregon. Masters Thesis, Portland state University, Portland, Oregon.

Columbia Region Association of Governments. 1975. Interim Action Program: Staff Report and Recommendations to the Board of Directors of Columbia Region Association of Governments. Portland, Oregon.

Columbia Region Association of Governments. 1974. Interim Action Program: Drainage Management in Johnson Creek Basin . Portland, Oregon.

Commonwealth of Pennsylvania. 1986. A Streambank Stabilization and Management Guide for Pennsylvania. Department of Environmental Resources, Harrisburg, Pennsylvania.

Cummins, K.W. 1974. Structure and function in stream ecosystems. Bioscience $24(8): 631-641$.

Davies, P.H. 1986. Toxicology and chemistry of metals in urban runoff. In, Proceedings of an Engineering Foundation Conference, Urban Water Research, American Society of Civil Engineers. Henniker, New Hampshire.

DeBano, I.F. and Schmidt, I.J. 1989. Improving Southwestern riparian areas through watershed management . General Technical Report RM182. U.S. Department of Agriculture Forest Service, Rocky Mountain Forest and Range Experiment station, Fort collins, Colorado.

Dolloff, C.A. 1986. Effects of stream cleaning on juvenile Coho salmon and Dolly Varden in southeast Alaska. Transactions American Fisheries Society 115:743-755.

Dunne, T. and Leopold, L. 1978. Water in Environmental Planning. W.H. Freeman and Company, San Francisco, California. 
Ellis, R.H. Fisheries biologist; personal communication, June 1992. Portland, Oregon.

Elmore, W. and Beschta, R.L. 1989. The fallacy of structures and the fortitude of vegetation. In, Proceedings of the California Riparian Systems Conference. General Technical Report PSW-110:116-119. U.S. Department of Agriculture Forest Service, Pacific Southwest Forest and Range Experiment Station, Berkeley, California.

Elser, A.A. 1968. Fish populations of a trout stream in relation to major channel habitat zones and channel alterations. Transactions American Fisheries Society $97(4): 389-397$.

Emery, J.C. 1977. Why nothing has happened: A case study of Johnson Creek. Report for Western Interstate Commission for Higher Education, Boulder, Colorado. U.S. Army Corps of Engineers, Water Resources Division, Portland, Oregon.

Everest, F.H. and Chapman, D.W. 1972. Habitat selection and spatial interaction by juvenile chinook salmon and steelhead trout in two Idaho streams. Journal Fisheries Research Board of Canada 29(1):91-100.

Everest, F.H. and Meehan, W.R. 1981. Forest management and anadromous fish habitat productivity. In, Transactions of the Forty-Sixth North American Wildlife Conference: 521-530. Wildlife Management Institute, Washington, D.C.

Ferguson, B.K. 1991. Urban stream reclamation. Journal of Soil and Water Conservation $46(5): 324-328$.

Foreman, R. (in press, due Fall 1994). Land Mosaics: The Ecology of Landscape and Regional Change. Cambridge University Press, Boston, Massachussetts.

Foreman, R. Landscape ecologist; personal communication, January 1994. Ipswich, Massachussets.

Fraser, J.M. 1981. Comparative survival and growth of planted wild, hybrid, and domestic strains of brook trout (Salvelinus fontinalis) in Ontario lakes. Canadian Journal of Fisheries and Aquatic Sciences 38:1672-1684.

Gary, H.L.; Ponce, S.L.; and Dedrick, J.D. 1981. Effects of mountain home developments on surface water quality: $A$ case study. Research Note RM-396. U.S. Department of Agriculture Forest Service, Rocky Mountain Forest and Range Experiment station, Fort collins, Colorado. 
Gray, J.R.A. and Edington, J.M. 1969. Effect of woodland clearance on stream temperature. Joumal Fisheries Research Board of Canada $26(2): 399-403$.

Greene, G.E. 1950. Land use and trout streams. Journal of Soil and Water Conservation 5:125-126.

Gregory, S.V. 1993. Ecosystem perspectives for stream assessment. Paper presented at stream Habitat Assessment Symposium, January 1993. Oregon State University, Department of Fish and Wildlife, Corvallis, Oregon.

Gregory, S.V.; Lambert, G.A.; and Moire, K.M.S. 1989. Influence of valley floor landforms on stream ecosystems. In, Proceedings of the California Riparian Systems Conference. General Technical Report PSW-110:3-8. U.S. Department of Agriculture Forest Service, Pacific southwest Forest and Range Experiment station, Berkeley, California.

Gregory, S.V.; Swanson, F.J.; McKee, W.A.; and Cummins, K.W. 1991. An ecosystem perspective of riparian zones. Bioscience $41(8): 540-551$.

Harmon, M.E. et al. 1986. Ecology of course woody debris in temperate ecosystems. Advances in Ecological Research 15:133-302.

Hartman, G.F. 1965. The role of behavior in the ecology and interaction of under-yearling coho salmon (Oncorhynchus kisutch) and steelhead trout (Salmo gairdneri) . Journal Fisheries Research Board of Canada $22(4): 1035-$ 1081 .

Hartman, G.F. and Brown, T.G. 1987. Use of small temporary, floodplain tributaries by juvenile salmonids in a west coast rain-forest drainage basin, Carnation Creek, British Columbia. Canadian Joumal of Fisheries and Aquatic Sciences $44(2): 262-270$.

Hawkins, C.P.: Murphy, M.L.: Anderson, N.H.; and Wilzbach, M.A. 1983. Riparian canopy and substrate composition interact to influence the abundance of salmonids, sculpins, and salamanders in streams. Canadian Journal of Fisheries and Aquatic Sciences 40:1173-1185.

Heede, B.H. 1986. Designing for dynamic equilibrium in streams. Water Resources Bulletin 22:351-357.

Heede, B.H. 1980. Stream Dynamics: an Overview for Land Managers. General Technical Report RM-72 . U.S. Department of 
Agriculture Forest Service, Rocky Mountain Forest and Range Experimentation Station, Fort Collins, Colorado.

Helfman, G.S. 1981. The advantage to fishes of hovering in shade. Copeia 1981:392-400.

Hogenson, G.M., and Foxworthy, B.I. 1965. Groundwater in the East Portland Area, Oregon. U.S. Geological Survey Water Supply Paper 1793, U.S. Government Printing Office, Washington, D.C.

Holtby, L.B. 1988. Effects of logging on stream temperatures in Carnation Creek, British Columbia, and associated impacts on the coho salmon (Onchorhynchus kisutch). Canadian Journal of Fisheries and Aquatic Sciences 45:502-515.

Hunter, C.J. 1991. Better Trout Habitat; $A$ Guide to Stream Restoration and Management. Montana Land Reliance, Island Press, Washington D.C.

Jobling, M. 1981. Temperature tolerance and the final preferendum - rapid methods for the assessment of optimum growth temperatures. Joumal of Fish Biology 19:439-455.

Johnson, R.R., and Jones, D.A., [eds.]. 1977. Importance, preservation, and management of riparian habitats: a symposium. General Technical Report RM-43. U.S. Department of Agriculture Forest Service, Rocky Mountain Forest and Range Experimentation Station, Fort Collins, Colorado.

Johnson, R.R.; Ziebell, C.D.; Patton, D.R.; Folliott, P.F.; and Hamre, R.H., [eds.]. 1985. Riparian ecosystems and their management; reconciling conflicting uses. First North American Riparian Conference. General Technical Report RM-120. U.S. Department of Agriculture Forest Service, Rocky Mountain Forest and Range Experimentation Station, Fort collins, Colorado.

Karr, J.R.; Toth, L.A.; and Dudley, D.R. 1985. Fish communities in midwestern rivers: a history of degradation. Bioscience $35(2): 90-95$.

Katz, M. and Gaufin, A.R. 1952. The effects of sewage pollution on the fish population of a midwestern stream. Transactions American Fisheries Society 82:156-165.

Keller, E.A. and Hoffman, E.K. 1977. Urban streams: Sensual blight or amenity? Joumal of Soil and Water Conservation $32: 237-240$. 
Knight, A.W. and Bottorff, R.L. 1984. The importance of riparian vegetation to stream ecosystems. In, Proceedings of the California Riparian Systems : 160-167. University of California Press, Berkeley, California.

Korostoff, N.P. 1990. Urban ecosystem restoration: The case of the forested urban stream valley park. In, Proceedings of the of First American Meeting for Ecological Restoration: 10-124. Society for Ecological Restoration, University of Wisconsin Arboretum, Madison, Wisconsin.

Leopold, L.; Wolman, M.; and Miller, T. 1964. Fluvial Processes in Geomorphology. W.H. Freeman, San Francisco, California.

Li, R.M. and Shen, H.W. 1973. Effect of tall vegetation and flow sediment. Joumal of the Hydraulics Division, American Society of Civil Engineers 9(HY5), Proceedings Paper 9748.

Limburg, K.E. and Schmidt, R.E. 1990. Patterns of fish spawning in Hudson River tributaries: Response to an urban gradient? Ecology 71:1238-1245.

Lotspeich, F. 1980. Watershed as the basic ecosystem. Water Resources Bulletin 16:581-586.

Lowrance, R.; Todd, R.; Fail, J. Jr.; Hendrickson, o. Jr.; Leonard,R.; and Asmussen, L. 1984. Riparian forests as nutrient filters in agricultural watersheds. Bioscience $34(6): 374-377$.

Machorro, E. Project manager on Johnson Creek for Bureau of Environmental Services. Personal communication, December 1993.

Marcus, M.D.; Young, M.K.; Noel, L.E.; and Mullan, B.A. 1990. Salmonid-Habitat Relationships in the Western U.S.: a review and indexed bibliography. General Technical Report RM-188. U.S. Department of Agriculture Forest Service, Rocky Mountain Forest and Range Experimentation Station, Fort Collins, Colorado.

Massey, J.B. 1990. Fisheries information on Johnson Creek. Informal report to Bureau of Environmental Services, City of Portland, Oregon.

Matthews, w.J. 1987. Physiochemical tolerance and selectivity of stream fishes as related to their geographic ranges and local distribution. In, Community 
and Evolutionary Ecology of North American Stream Fishes: 111-120. University of Oklahoma Press, Norman, Oklahoma.

Matthews, w.J. and Gelwick, F.P. 1990. Fishes of Crutcho Creek and the North Canadian River in central Oklahoma: Effects of Urbanization. The Southwest Naturalist 35:403-410.

Matthews, W.J. and Maness, J.D. 1979. Critical thermal maxima, oxygen tolerances and population fluctuations in southwestern stream fishes. American Midland Naturalist $102: 374-377$.

Meehan, W.R. 1970. Some effects of shade cover on stream temperatures in southeast Alaska. Research Note PNW-113. U.S. Department of Agriculture Forest Service, Pacific Northwest Forest 8and Range Experiment Station, Portland, Oregon.

Meehan, W.R.; Swanson, F.J.; and Sedell, J.R. 1977. Influences of riparian vegetation on aquatic ecosystems with particular reference to salmonid fishes and their food supply. In, Importance, Preservation and Management of Riparian Habitat: A Symposium. General Technical Report RM-43: 37145. U.S. Department of Agriculture Rocky Mountain Forest and Range Experiment station, Fort Collins, colorado.

Metropolitan Service District. Undated. Metropolitan Greenspaces brochure. Metropolitan Service District, Portland, oregon.

Metropolitan Service District. 1991. Johnson Creek II: Background Report. Metropolitan Service District, Portland, oregon.

Metropolitan Service District. 1982. Johnson Creek Options for Citizens. Metropolitan Service District, Portland, oregon.

Metropolitan Service District. 1981. Along Johnson Creek: A Guide to Historical Sites and Natural Resources. Metropolitan Service District, Portland, Oregon.

Metropolitan Service District. 1980a. Regional Stormwater Management Plan: Ordinance, Findings, Plan Text, and Plan Maps. Metropolitan Service District, Portland, oregon.

Metropolitan Service District. 1980b. Preliminary Engineering Repor: Johnson Creek Flood Control and Pollution Abatement Project. Metropolitan Service District, Portland, Oregon. 
Metropolitan Service District. 1980c. Flood Control Pollution Abatement Project. Metropolitan Service District, Portland, Oregon.

Metropolitan Service District. 1980d. Johnson Creek Background Report I. Metropolitan Service District, Portland, Oregon.

Metropolitan Service District. 1976. Drainage Management for the Johnson Creek Drainage. Portland, Oregon.

Metropolitan Service District. 1975. Drainage Management in the Johnson Creek Basin. Metropolitan Service District, Portland, Oregon.

Metropolitan Service District. 1974. Proposed Drainage Management for the Johnson Creek Basin. Metropolitan Service District, Portland, Oregon.

Meyer, P.A. 1989. Riparian and related values associated with flood control project alternatives at wildcat Creek and San Pablo Creeks. In, Proceedings of the California Riparian Systems Conference. General Technical Report PSW-110:491494. U.S. Department of Agriculture Forest Service, Pacific Southwest Range and Experiment Station Berkeley, California.

Moore, K.M.S. and Gregory, S.V. 1989. Geomorphic and riparian influences on the distribution and abundance of salmonids in a Cascade Mountain stream. In, Proceedings of the Califormia Riparian Systems Conference. General Technical Report PSW-110:256-261. U.S. Department of Agriculture Forest Service, Pacific Southwest Range and Experiment station Berkeley, California.

Moring, J.R. 1975. The Alsea watershed study: effects of logging on the aquatic resources of three headwater streams of the Alsea River, Oregon. Part III - Discussion and Recommendations. Oregon Department of Fish and Wildlife, Portland, Oregon. Fisheries Research Report: 9.

Moring, J.R.; Gorman, G.C.; and Mullen, D.M. 1985. The value of riparian zones for protecting aquatic systems: general concerns and recent studies in Maine. In, Riparian Ecosystems and Their Management: Reconciling Conflicting Uses. General Technical Report RM-120:315-319. U.S. Department of Agriculture Rocky Mountain Forest and Range Experiment Station, Fort collins, Colorado. 
Moring, J.R. and Lantz, R.I. 1974. Immediate effects of logging on the freshwater environment of salmonids. Oregon Wildlife Commission Research Division, Portland, oregon. Project AFS-58.

Narver, D.W. 1972. A survey of some possible effects of logging on two eastern Vancouver Island Streams. Joumal Fisheries Research Board of Canada . Technical Report 323.

National Oceanic and Atmospheric Administration. 1991. Local Climatological Data: Portland, Oregon, Annual Summary with Comparative Data. U.S. Dept. of Commerce, National Climatic Center, Asheville, N.C.

Nehlsen, W.; Lichatowich, J.A.; and Williams, J.E. 1992 . Pacific salmon and the search for sustainability. Renewable Resources Journal $10(2): 20-26$.

Nehlsen, W.; Williams, J.E.; and Lichatowich, J.A. 1991. Pacific salmon at the crossroads: stocks at risk from California, Oregon, Idaho, and Washington. Fisheries $16(2): 4-21$.

Oregon Department of Fish and Wildlife. Undated. STEP (Salmon Trout Enhancement Program). Oregon Department of Fish and wildlife Brochure, Portland, Oregon.

Oregon Department of Fish and Wildlife. 1990. Volume II: Miscellaneous papers and sampling information pertaining to Johnson Creek. Portland, Oregon.

Oregon Department of Fish and Wildlife. 1989. Volume I: Miscellaneous papers and sampling information pertaining to Johnson Creek. Portland, Oregon.

oregon Department of Environmental Quality. 1975. Water Quality in Johnson Creek, 1970-1975 . Oregon Department of Environmental Quality, Portland, Oregon.

Oregon Department of Water Resources. 1990. Water Resources of Johnson Creek. Oregon Department of Water Resources, salem, Oregon.

Ortiz, B. 1989. Redesign of a flood control project by citizen initiative. In, Proceedings of the California Riparian Systems Conference. General Technical Report PSW-110:495-500. U.S. Department of Agriculture Forest Service, Pacific Southwest Range and Experiment Station Berkeley, California. 
Patten, D.T. and Hunter, W.C. 1989. Formation of the Arizona Riparian Council: An example of lasting public interest in riparian resources. In, Proceedings of the Califormia Riparian Systems Conference. General Technical Report PSW110:537-539. U.S. Department of Agriculture Forest Service, Pacific Southwest Range and Experiment station Berkeley, California.

Payne, N.F., and Copes, F. 1986. Wildlife and Fisheries Improvement Handbook. U.S. Department of Agriculture Forest Service, Washington, D.C. Wildlife and Fisheries Administrative Report.

Pedersen, E.R. and Perkins, M.A. 1986. The use of benthic invertebrate data for evaluating impacts of urban runoff. Hydrobiologia $139: 13-22$.

Peterson, w. 1989. Innovations in stream restoration and flood control design meeting flood capacity and environmental goals on San Luis Obisbo Creek. In, Urban Wetlands, Proceedings of the National Wetland Symposium : 501-505. Association of Wetland Managers, Berne, New York.

Platts, W.S. 1983. Vegetation requirements for fisheries habitat. In, Proceedings of Managing Intermountain Rangelands-Improvement of Range and Wildlife Habitats. General Technical Report INT57:184-188. U.S. Department of Agriculture Forest Service, Intermountain Forest and Range Experiment Station, Ogden, Utah.

Portland State University. 1981. Interpretive Report: Portland Metropolitan Area Urban Stormwater Runoff Study. Portland State University, Portland, Oregon.

Reiser, D.W. and Bjornn, T.C. 1979. Volume 1: Influence of Forest and Rangeland Management on Anadromous Fish Habitat in Western North America; Habitat Requirements of Anadromous Salmonids. General Technical Report PNW-96. U.S. Department of Agriculture Forest Service, Pacific Northwest Forest and Range Experiment station, Portland, oregon.

Reiser, D.W.; Ramey, M.P.; and Lambert, T.R. 1987. Considerations in assessing flushing flow needs in regulated stream systems. In, Craig, J.F. and J.B. Kemper [eds.]. Regulated Stream Advances in Ecology: 45-57. Plenum Press, New York, New York.

Riley, A.L. 1989. The Wildcat-San Pablo Creek Flood control project and its implications for the design of 
environmentally sensitive flood management plans. In, Proceedings of the Califormia Riparian Systems Conference. General Technical Report PSW-110:485-490. U.S. Department of Agriculture Forest Service, Pacific Southwest Range and Experiment station Berkeley, California.

Riley, A.L. 1988. A new state role in flood damage reduction: Low cost, timely stream restoration projects In, Urban Wetlands, Proceedings of the National Wetland Symposium. Association of Wetland Managers, Berne, New York.

Salo, E.O. and Cederhol, C.J. 1980. Cumulative effects of forest management on watersheds-some aquatic considerations. In, Cumulative Effects of Forest Management on California Watersheds: 67-78. University of California, Berkeley, California.

Salo, E.0. and Cundy, T. [eds.]. 1987. Streamside Management: Forestry and Fisheries Interactions 57:4-6. University of Washington, seattle, washington.

Schillinger, J.E. and Stuart, D.G. 1978. Quantification of non-point water pollutants from logging, cattle grazing, mining, and subdivision activities . Montana University Joint Water Resources Research Center, Montana State University, Bozeman, Montana. MUJWRCC Report 93.

Schlosser, I.J. 1991. Stream fish ecology: a landscape perspective. Bioscience 41(10):704-712.

Scott, J.B.; Steward, C.R.; and Stober, Q.J. 1986. Effects of urban development on fish population dynamics in Delsey Creek, Washington. Transactions of the American Fisheries Society 115:555-567.

Sedell, J.R. and Luchessa, K.J. 1981. Using the historical record as an aid to salmonid habitat enhancement In, Symposium on Acquisition and Utilization of Aquatic Habitat Inventory Information . Portland, Oregon. Hagen Publishing, Billings, Montana.

Sedell, J.R., and Triska, F.J. 1977. Biological consequences of large organic debris in Northwest streams. In, Logging Debris in Streams Workshop, Oregon State University, Corvallis, Oregon.

Segall, B.A. 1976. The Impact of Vacation Homes on National Forest Water Resources. U.S. Department of Agriculture Forest Service, Rocky Mountain Forest and Range Experiment Station, 
Fort Collins, Colorado. Eisenhower Consortium Bulletin 3 .

Seltzer, E. 1983. Citizen Participation in Environmental Planning. Doctoral dissertation, University of Pennsylvania, Philadelphia, Pennsylvania.

Sloane-Richey, J.; Perkins, M.A.; and Malueg, K.W.' 1981. The effects of urbanization and stormwater runoff on the food quality in two salmonid streams. Verhandlungen, Internationale Vereinigung fur Theoretische und Angewandte Limnologie 21:812-818.

Smith, C.T. 1969. The drainage basin as a historical basis for human activity In, Chorley, R. [ed.] Introduction to Geographical Hydrology: 20-29. Methuen and Company, London, England.

Sullivan, K.; Lisle, T.E.; and Dolloff, C.A. 1987. Stream channels: the link between forest and fishes. In, Streamside Management: Forestry and Fisheries Interactions 57:39-97. University of Washington, Seattle, washington.

Swanson, F.J.; Gregory, S.V.; sedell, J.R.; and Campbell, A.G. 1982. Land-water interactions: The riparian zone In, Analysis of coniferous forest ecosystems in the western U.S. 14:267-291. Hutchinson Ross Publishing Company, Stroudburg, Pennsylvania.

Swanson, F.J. and Lienkaemper, G.W. 1978. Physical consequences of large organic debris in Pacific Northwest streams. General Technical Report PNW-69. U.S. Department of Agriculture Forest Service, Pacific Northwest Forest and Range Experiment Station, Portland, Oregon.

Swanson, F.J.: Lienkaemper, G.W.; and Sedell, J.R. 1976. History, physical effects, and management implications of large organic debris in western Oregon streams. General Technical Report PNW-56. U.S. Department of Agriculture Forest Service, Pacific Northwest Forest and Range Experiment Station, Portland, Oregon.

Teclaff, L.A. 1967. The river basin in history and law. Martinus Nijhoff, Den Haag, Nederlands.

Toole, C.; Wyatt, B.; Sommarstrom, S.; and Hashagen, K. 1983. Report of the First California Salmon and Steelhead Restoration Conference. University of California, Bodega Bay, California.

Tramer, E.J. and Rogers, P.M. 1973. Diversity and longitudinal zonation in fish populations of two 
streams entering a metropolitan area. American Midland Naturalist $90: 366-374$.

Trautman, M.B. 1933. The General effect of pollution on Ohio fishlife. Transactions American Fisheries Society 63:69-72.

U.S. Army Corps of Engineers. Undated. Johnson Creek Flood Control Project - Hydrology/Hydraulics Study, Draft. U.S. Army Engineer District, Portland, Oregon.

U.S. Army Corps of Engineers. 1992. Johnson Creek at Portland and Vicinity: Willamette River Basin Flood Control Improvement Reconnaissance Report . U.S. Army Engineer District, Portland, Oregon.

U.S. Army Corps of Engineers. 1990. Willamette River Basin Flood Control Improvement Reconnaissance Draft Report and Appendices: Johnson Creek at Portland and Vicinity. U.S. Army Engineer District, Portland, Oregon.

U.S. Army Corps of Engineers. 1986. Excerpts from Post Flood Reports on Johnson Creek and Vicinity. U.S. Army Engineer District, Portland, Oregon.

U.S. Army Corps of Engineers. 1982. Johnson Creek Cross Sections: COE 009-010. U.S. Army Engineer District, Portland, Oregon.

U.S. Army Corps of Engineers. 1975a. Portland-Vancouver Metropolitan Area Water Resources Study. U.S. Army Engineer District, Portland, Oregon.

U.S. Army Corps of Engineers. 1975b. Design Memorandum Johnson Creek at Portland and Vicinity: Willamette River Basin Flood Control Improvement Restudy. U.S. Army Engineer District, Portland, Oregon.

U.S. Army Corps of Engineers. 1973. Post Flood Report: Floods of January 1972. U.S. Army Engineer District, Portland, oregon.

U.S. Army Corps of Engineers. 1958. Design Memorandum Johnson Creek at Portland and Vicinity: Willamette River Basin Flood Control Improvement. U.S. Army Engineer District, Portland, Oregon.

U.S. Environmental Protection Agency. 1982. Willamette Valley Stream Survey: Environmental Assessment Team Electrofishing Data . Corvall is Field station, Corvallis, Oregon.

U.S. Fish and Wildlife Service. 1992. List of endangered and threatened species that may be present within the area of the proposed Johnson Creek Management Plan 
in Multnomah and Clackamas Counties, Oregon. U.S. Department of the Interior, Portland Field Station, Portland, Oregon.

U.S. Forest Service. 1990. Stream Inventory Handbook. Region 6, Version 5. U.S. Department of Agriculture, Pacific Northwest Research Station, Portland, Oregon.

U.S. Forest Service. 1988. Fisheries Habitat Evaluation Handbook FSH2609.23. U.S. Department of Agriculture, Rocky Mountain Region, Lakewood, Colorado.

U.S. Geological Survey. 1991. Draft: Surface Water Quality Assessment of the Johnson Creek Basin. U.S. Department of Interior, Water Resources Division, Portland, Oregon.

U.S. Geological Survey. 1990a. Statistical Summaries of Streamflow Data in Oregon. Volume I - Monthly and Annual Streamflow and Flow-Duration Values. Open File Report 90-118. U.S. Department of Interior, Water Resources Division, Portland, Oregon.

U.S. Geological Survey. 1990b. Statistical Summaries of Streamflow Data in Oregon. Volume II - Western Oregon. Open File Report 84-454. U.S. Department of Interior, Water Resources Division, Portland, Oregon.

U.S. Geological Survey. 1989. Project Proposal: Johnson Creek Water Quality Assessment. U.S. Department of Interior, Water Resources. Division, Portland, Oregon.

U.S. Geological Survey. 1985. 7.5 Minute Series Topographic Map for Sandy, Oregon. U.S. Department of Interior Geological Survey, Denver, Colorado.

U.S. Geological Survey. 1984. 7.5 Minute Series Topographic Maps for Lake Oswego, Gladstone, and Damascus, Oregon. U.S. Department of Interior Geological Survey, Denver, Colorado.

U.S. Soil Conservation Service. 1985. Soil Survey of Clackamas County Area, Oregon. U.S. Department of Agriculture, U.S. Government Printing office, Washington D.C.

U.S. Soil Conservation Service. 1983. Soil Survey of Multnomah County, Oregon. U.S. Department of Agriculture, U.S. Government Printing office, Washington D.C.

U.S. Soil Conservation Service. 1969. Johnson Creek Watershed Investigation Report, Willamette River Basin Survey, Multnomah and Clackamas Counties, 
Oregon. U.S. Department of Agriculture, Portland, Oregon.

Vannote, R.L.; Minshall, G.W.: Cummins, K.W.; Sedell, J.R.: and Cushing, C.E. 1980. The river continuum concept. Canadian Journal of Fisheries and Aquatic Sciences 37:130-137.

Vendlinski, T.J. and Talley, S.N. 1989. Public participation and natural habitat preservation along Arcade Creek, Del Paso Regional Park, Sacramento, California. In, Proceedings of the California Riparian Systems Conference. General Technical Report PSW-110:506-511. U.S. Department of Agriculture Forest Service, Pacific Southwest Range and Experiment Station Berkeley, California.

Wesche, T.A.; Goertler, C.M.; and Frye, C.B. 1987. Contribution of riparian vegetation to trout cover in smaller trout streams. North American Joumal of Fisheries Management $7: 232-237$.

Westfall, G. 1983. Salmon and Trout Enhancement Program (STEP) Restoration Projects in Oregon. In, Report of the First California Salmon and Steelhead Restoration Conference. University of California, Bodega Bay, California.

Whitmore, C.M.; Warren C.E.; and Doudoroff, P. 1960. Avoidance reactions of salmonids and centrachid fishes to low oxygen concentrations. Transactions American Fisheries Society $6: 201-207$.

Williams, J.E. et al 1989. Fishes of North America endangered, threatened, or of special concern. Fisheries $14(6): 2-20$.

Williams, P.B. February 1993. Presentation on urban stream planning. Portland State University, Portland, oregon.

Williams, P.B. and Swanson, M.L. 1989. A new approach to flood protection design and riparian management. In, Proceedings of the California Riparian Systems Conference. General Technical Report PSW-110:40-46. U.S. Department of Agriculture Forest Service, Pacific Southwest Range and Experiment Station, Berkeley, California.

Wilzbach, M.A.; Cummins, K.W.; and Hall, J.D. 1986. Influence of habitat manipulations on interactions between cutthroat trout and invertebrate drift. Ecology $67: 898-911$. 
Windell, J.T.; Rink, L.P.; and Lacy, G.M. 1988. Riparian habitat and streamside protection in Boulder, Colorado: The Boulder Creek Corridor Project In, Urban Wetlands, Proceedings of the National Wetland Symposium: 278-284. Association of Wetland Managers, Berne, New York. 